\title{
Credit Expansion in Emerging Markets: Propeller of Growth?
}




\title{
WP/15/212
}

\section{IMF Working Paper}

\section{Credit Expansion in Emerging Markets: Propeller of Growth?}

\author{
by Mercedes Garcia-Escribano and Fei Han
}

IMF Working Papers describe research in progress by the author(s) and are published to elicit comments and to encourage debate. The views expressed in IMF Working Papers are those of the author(s) and do not necessarily represent the views of the IMF, its Executive Board, or IMF management.
I $N$
E
N A T I O N A L
$M O N E T A R Y$
F U N D 


\title{
IMF Working Paper
}

Western Hemisphere Department

\section{Credit Expansion in Emerging Markets: Propeller of Growth?}

Prepared by Mercedes Garcia-Escribano and Fei Han ${ }^{1}$

Authorized for distribution by Alfredo Cuevas

September 2015

\section{IMF Working Papers describe research in progress by the author(s) and are published to elicit comments and to encourage debate. The views expressed in IMF Working Papers are those of the author(s) and do not necessarily represent the views of the IMF, its Executive Board, or IMF management.}

\begin{abstract}
This paper explores the contribution of credit growth and the composition of credit portfolio (corporate, consumer, and housing credit) to economic growth in emerging market economies (EMs). Using cross-country panel regressions, we find significant impact of credit growth on real GDP growth, with the magnitude and transmission channel of the impact of credit on real activity depending on the specific type of credit. In particular, the results show that corporate credit shocks influence GDP growth mainly through investment, while consumer credit shocks are associated with private consumption. In addition, taking Brazil as a case study, we use a time series model to examine the role that the expansion and composition of credit played in driving real GDP growth in the past. The results of the case study are consistent with those found in the cross-country panel regressions.

JEL Classification Numbers: E44, E50, E51
\end{abstract}

Keywords: Credit Growth, Economic Growth, Emerging Markets

Authors' email addresses: mgarciaescribano@imf.org, fhan@imf.org.

\footnotetext{
${ }^{1}$ We would like to thank Alfredo Cuevas, Martin Kaufman, the Brazil Central Bank, the Brazil Ministry of Finance, and participants at the IMF Western Hemisphere seminar series for their feedback. The paper has benefited from the discussions at the International Atlantic Economic Conference held in April in Madrid, where the paper was presented.
} 


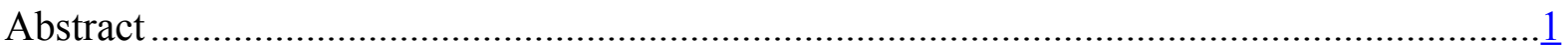

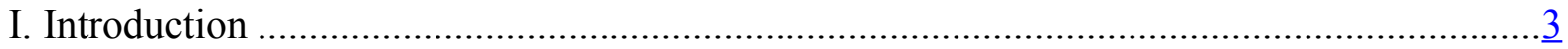

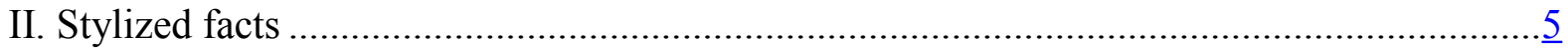

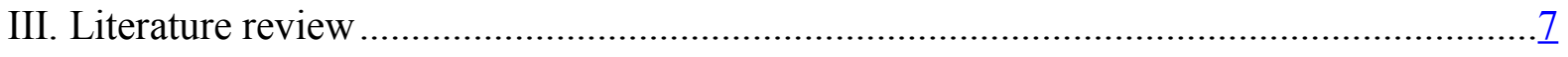

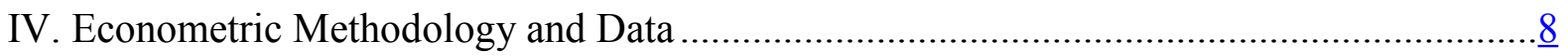

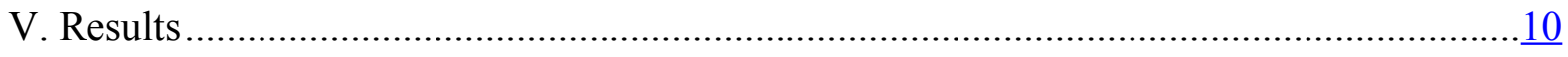

VI. Case Study: Brazil ............................................................................................. 12

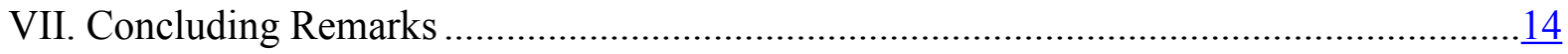

Appendices

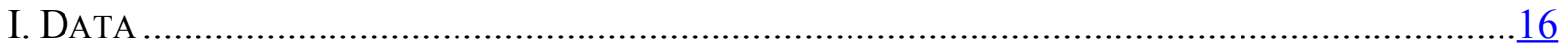

II. Cross-Country Dynamic Panel Regressions Results .................................................. $\frac{17}{21}$

III. Brazil-Specific VARX: Impulse Responses to One-Standard-Deviation Shocks ..............21

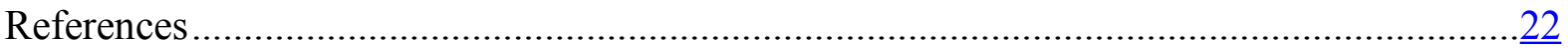




\section{INTRODUCTION}

Credit in emerging market economies has been growing very rapidly during the past decade. Several factors - including for example, macroeconomic stability, financial deepening, availability of new lending instruments, and also economic growth - help explain the recent strong expansion of credit in emerging markets (EMs). In some countries, like Brazil, Indonesia, Russia, and Turkey, average credit growth exceeded 10 percent per annum during the past decade. Other countries show more moderate rates of credit expansion.

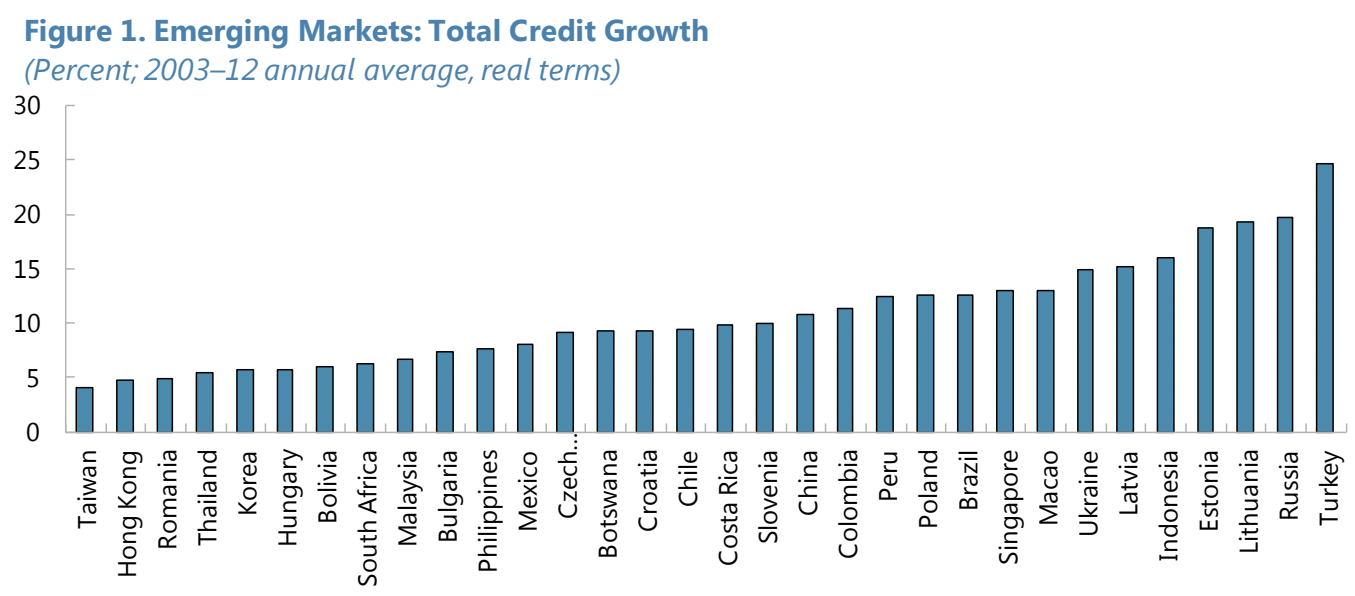

Sources: Haver Analytics; dXtime database; and Fund staff calculations.

Countries also differ in the composition of their credit portfolio. The composition of the credit portfolio and in particular the contribution of each type of loan-corporate, consumer and housing - to the expansion of the stock of credit has been different across EMs (as shown in Figure 2). ${ }^{2}$ For instance, Brazil, Indonesia and Turkey are among the countries with the largest contribution of consumer credit to the credit expansion. Specifically, in these three countries the expansion of consumer and corporate credit have contributed broadly equally to credit growth, while in others like Chile, China, and Singapore, corporate loans explain the bulk of the observed increase in credit.

The main questions our paper addressed are: What has been the impact of credit growth on GDP growth? Has the composition of credit (i.e. corporate, consumer, and housing credit) mattered for GDP growth? These questions are very relevant for EMs, where financial development continues to deepen, and therefore, the composition of the expansion of credit could have a potential different impact on their prospects of economic growth. This paper builds and complements the existing literature as the analysis of the impact of the change in credit composition on output is novel, particularly using a cross-country panel analysis. In addition to the benefits associated to credit expansion, unfortunately, risks may stem from episodes of rapid credit growth. Though not the focus of this paper, the risks associated to

\footnotetext{
2 This paper uses housing credit and mortgage indistinctively.
} 
excessive credit growth cannot be ignored even if historically only a minority of the credit booms has ended in a credit bust.

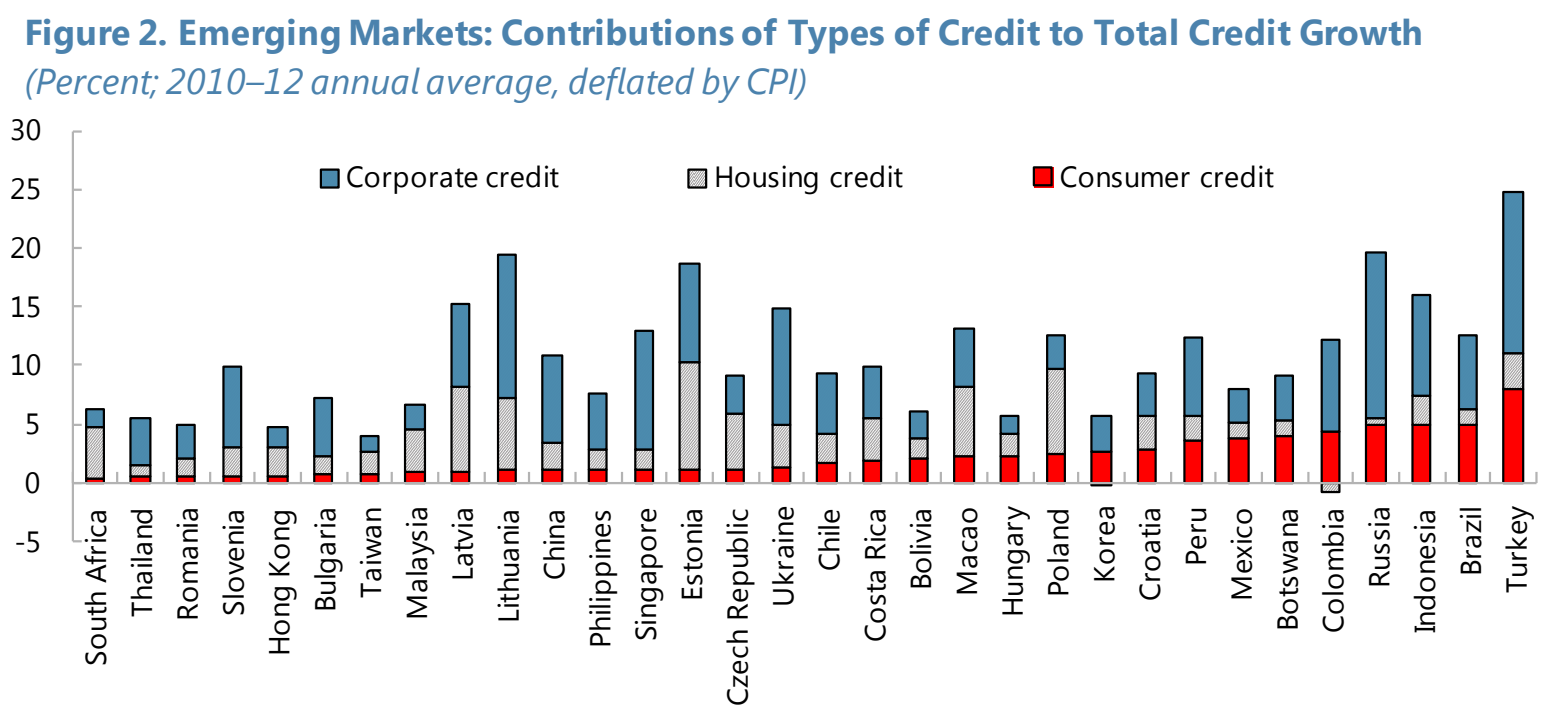

Sources: Haver Analytics; dXtime database; and Fund staff calculations.

This paper explores the impact of bank lending and its composition on GDP growth in EMs. A cross-country regression for a panel comprising 31 EMs for the period 2002-12 is used to assess the effects of corporate, consumer, and housing credit on real GDP growth, as well as on consumption and investment. The results confirm the different impact of consumer, corporate and housing credit on economic growth. In particular, evidence is presented showing that consumer credit has a significantly positive effect on consumption but on not investment. On the other hand, corporate credit seems to have an impact on investment but not on consumption. At the same time, there seems to be some evidence suggesting that mortgage also contributes to economic growth through increasing consumption, although the evidence is only significant in two out of three empirical specifications. These findings are in line with most empirical literature. For consumer credit, Ludvigson (1999), for instance, also finds that growth in consumer credit is significantly related to consumption growth using aggregate data for the U.S. For corporate credit, Brigden and Mizen (1999) finds empirical evidence for the credit channel in the U.K. corporate sector, i.e. a positive impact of bank lending on corporate investment. For the housing credit, our finding tends to suggest a positive relationship between household consumption and mortgages, which might be due to the impact of house prices. Rising house prices, on the one hand, could have a wealth effect on household consumption by increasing households' perceived wealth or by relaxing borrowing constraints (Campbell and Cocco, 2007). Mian and Sufi (2014) also find that, as part of mortgage loans, cash-out mortgage refinancing has a large impact on household spending. In addition, mortgages could also have an impact on investment through housing construction, but we did not find evidence supporting this hypothesis. ${ }^{3}$ Finally, a case study

\footnotetext{
${ }^{3}$ Other papers, like the one by Peek and Wilcox (2006), find a negative relationship between mortgage interest rates and residential investment, implying a positive impact of mortgage loans on investment.
} 
on Brazil is presented and findings, using a country-specific VARX model, are consistent with those found in the cross-country panel analysis.

The rest of the paper is organized as follows. Section II presents some stylized facts of the credit expansion that EMs have experienced and of its relation with economic growth. This section also overviews previous work on the relationship credit and economic growth.

Section III describes the dataset and the empirical cross-country panel regression approach. Results are presented in Section IV. Section V describes in detail the recent credit developments in Brazil and examines using an alternative specification the dynamic effects of credit composition on GDP growth in this country. Section IV summarizes the main findings and concludes.

\section{STYLIZED FACTS}

The past decade has been characterized by a rapid credit expansion in most EMs. On average, banking credit accounted for about 73 percent of GDP by end-2012 (compared to 42 percent in 2003) (Figure 3). Credit dynamics changed significantly throughout the period. The sub-period up to 2008 is characterized by strong credit growth. During the 2008-09 global financial crisis credit growth receded. In the more recent sub-period, 2010-12, credit growth picked-up, though on average remained well below the pre-crisis period rates. It is also interesting to note that throughout the decade, corporate credit has explained the bulk of credit growth, followed by mortgages and consumer credit. Many factors, including macroeconomic stability, real income gains, the development of the domestic capital markets, which permitted the introduction of new financial instruments, have favored this process and explain the changes in the dynamics. Financial liberalization and the surge in capital flows to EMs amidst increased global liquidity have also played an important role.
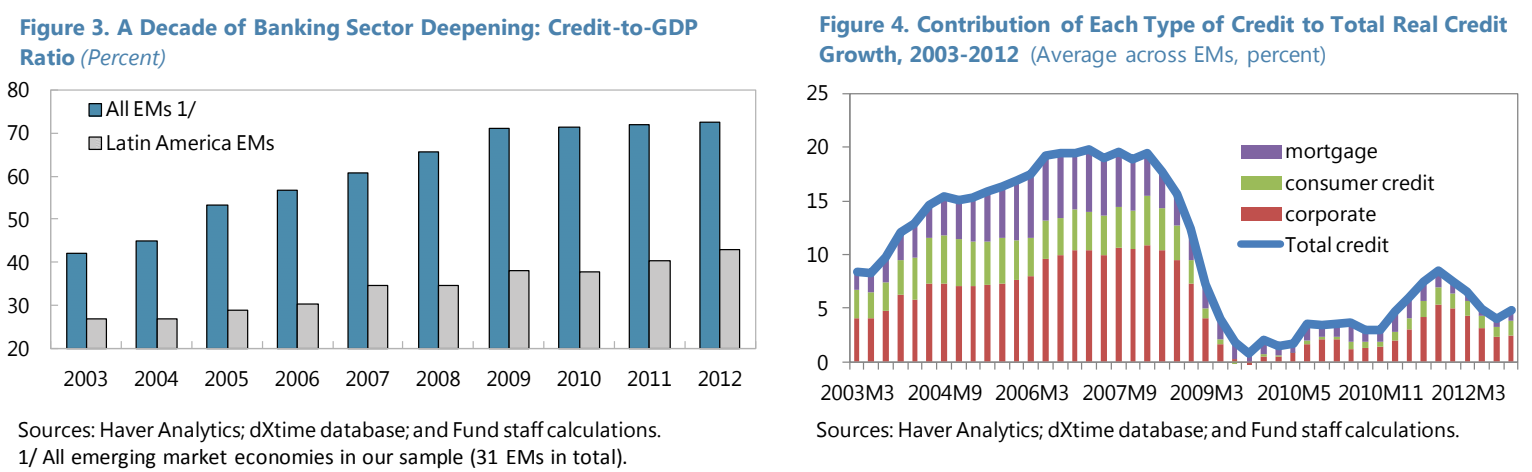

While part of the credit growth has been associated to the process of financial deepening, an excessive credit expansion - in other words, credit booms - may have also taken place in these economies, resulting in the build-up of vulnerabilities that raise the risk of a banking crisis. During credit booms, lending standards may loosen and excessive leverage and asset price bubbles follow. Though very costly for economic activity and the financial system, only a few cases of credit booms have ended up in crisis. In particular, a third of boom cases have ended up in financial crises, while other credit episodes have been followed by extended periods of below-trend economic growth and others have resulted in permanent financial deepening and benefit long-term economic growth (Dell'Ariccia et al (2012)). 
Across the EMs, there are differences in the current level of credit and the past speed of growth. For example, in Latin America, where credit more than doubled during 2003-12, the current average level of financial deepening continues to be below the average EM. There is also dispersion across the Latin America economies in their past credit growth and current credit levels. Chile continues to be the country with larger stock of credit in percent of the country's

Figure 5. Latin AmericaA Decade of Banking Sector Deepending: Credit-to-GDP Ratio (Percent)

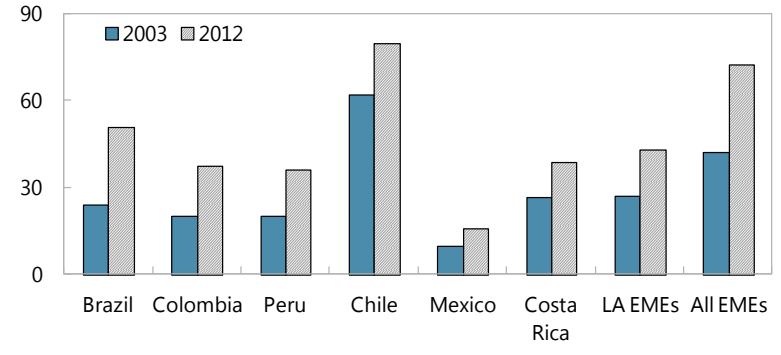

Sources: Haver Analytics; dXtime database; and Fund staff calculations. GDP, and Mexico with the smaller one.

In addition to the differences mentioned above, there is dispersion in the composition of the credit growth. Figure 2 showed the contribution of each type of credit to the total credit growth. As result of this process, countries differ in their current composition of the stock of credit. Mortgages represent about 60 percent of total credit in Hong Kong and less than 10 percent in Colombia, Korea, Russia, and Ukraine. Corporate credit accounts for the bulk of credit in several Asian and European EMs, such as China, Philippines, Thailand and Russia.

Figure 6. Credit Portfolio, by Type of Credit, 2012 (Percent of total credit)

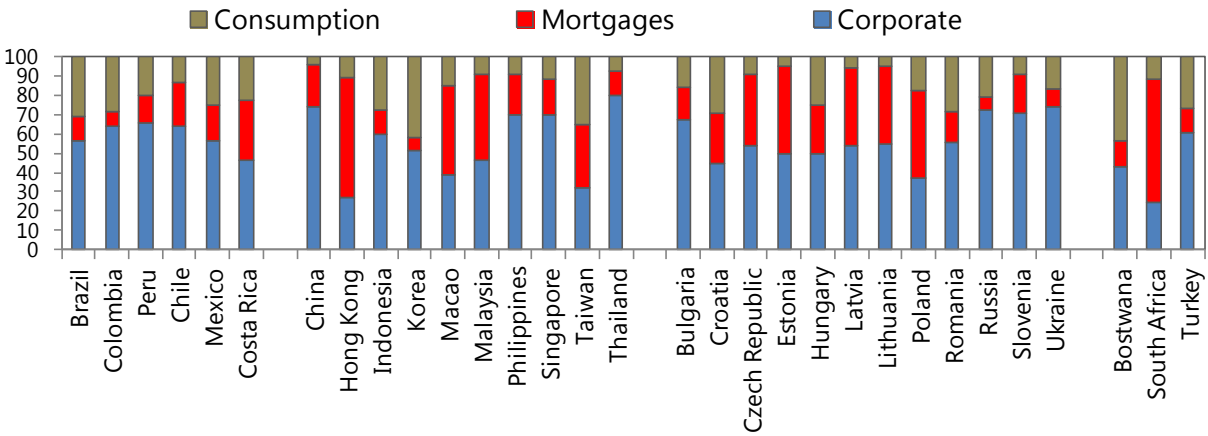

Sources: Haver Analytics; dXtime database; and Fund staff calculations.

The period of buoyant credit has been accompanied by a relatively strong economic growth. Figure 7 shows a positive association between credit and economic growth, and this correlation persists when focusing on consumer (corporate) credit and GDP growth (Figures 8.a. and 8.b.). The causality of this relationship and the channels through which credit impacts growth will be examined in the next section.

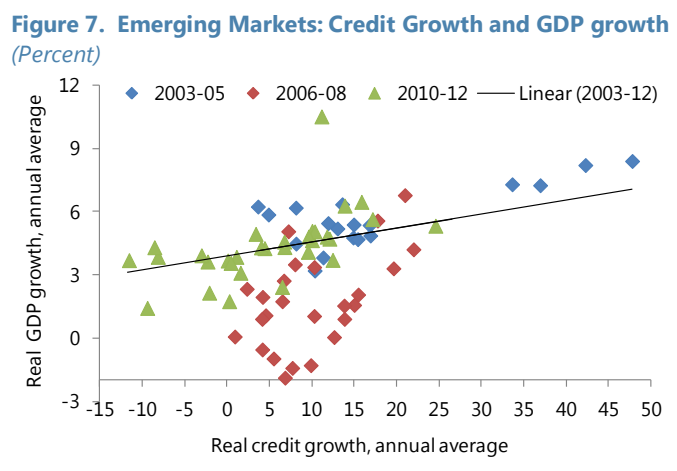

Sources: Haver Analytics; dXtime database; and Fund staff calculations. 


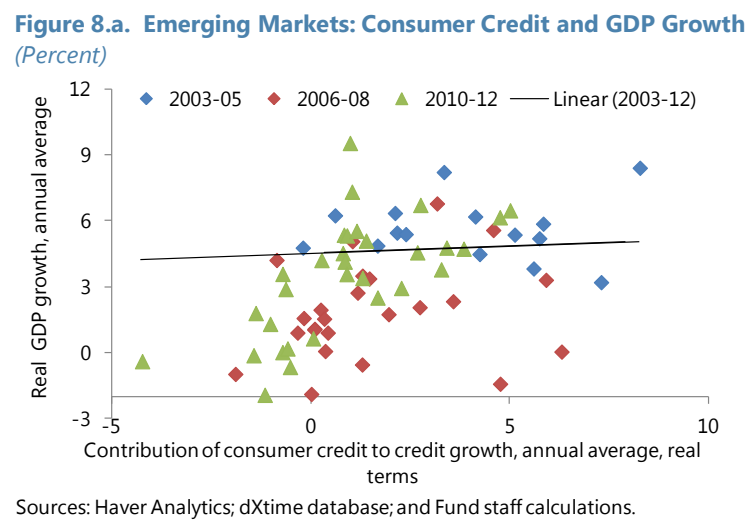

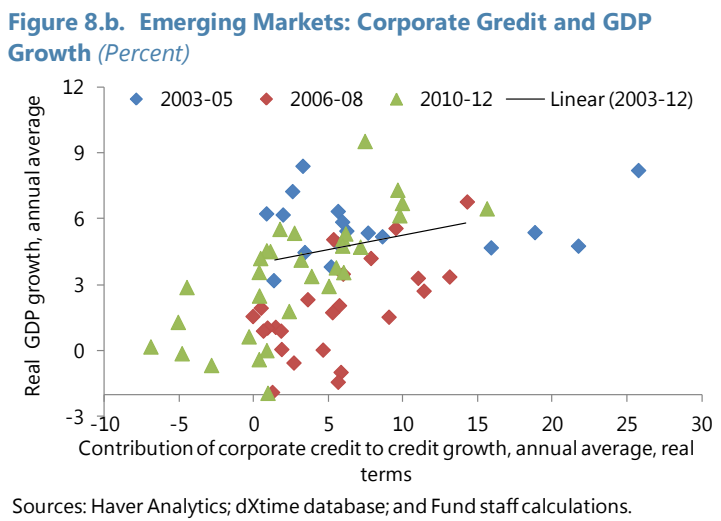

\section{LITERATURE REVIEW}

The theoretical underpinnings of the linkages between economic activity and credit growth are well known (see, for instance, Levine, 2004 and Harrison, Sussman, and Zeira, 1999). However, the empirical analysis of such relationship entails difficulties, and findings are mixed. While credit allows for greater economic growth through higher investment and consumption, greater economic growth also fosters credit growth as economic activity boosts collateral values and improves creditworthiness, for example, through the decline in unemployment. The endogeneity between credit and GDP is a challenge for the empirical analysis. A variety of instrument variables have been proposed to solve this problem. For instance, Peek et al. (2003) identified the effects of loan supply shocks on GDP in the U.S. with time series regressions using bank health measures for the banking sector as instruments for bank supply shocks. Bassett et al. (2010) used bank-level data to construct a measure of loan supply shocks for the U.S. and found economically large effects on economic growth. Using panel regressions with state-level data of the U.S. and with state-specific money demand shocks as instruments, Driscoll (2004) did not find significant effects of bank loans on output. However, by applying the same methodology to the euro-area countries, Rondorf (2012) found significant effects of bank loans on output growth. Miron et al. (1994) found no evidence for change in the lending channel of monetary policy over time; given the increasing availability of financing from other sources, the importance of the lending channel might have weakened.

There has been relatively limited research on the effects of credit composition on economic activity. Using aggregate time-series data for the U.S., Ludvigson (1999) finds a positive relationship between the growth of consumer credit and consumption. Although the permanent income hypothesis $(\mathrm{PIH})$ predicts that the demand for credit would passively respond to the demand for consumption (Hall, 1978; Flavin 1981), the time-varying liquidity constraint model proposed by Ludvigson (1999) could correctly predict the positive relationship. Using aggregate time-series data for the U.K, Brigden and Mizen (1999) finds that there is empirical evidence for the influence of credit on the investment of the U.K. corporate sector. Mian and Sufi (2014) investigates the relationship between household spending and mortgage refinancing, and concludes that cash-out refinancing in response to house price growth has a very large effect on household spending. Perhaps the closest study to ours is Beck et al (2012), which examines the impact of credit composition on economic 
growth and finds that corporate credit — but not household credit) - has a significantly positive impact on the growth of GDP per capita. However, their cross-section regression with data averaged over the sample period does not capture the dynamics of credit growth.

\section{Econometric Methodology And Data}

Cross-country panel regressions are used to assess the effects of corporate, consumer, and housing credit on real GDP growth, as well as the transmission channels, namely, through either consumption or investment. ${ }^{4}$ Identifying the transmission channels is important because of the policy implications. EMs display different growth models such as consumption- or investment-led growth (Figure 9). Private consumption has been an important pillar of economic growth in countries like Brazil and Ukraine, ${ }^{5}$ while in countries like Turkey and Estonia, investment has been a larger contributor to growth than private consumption.

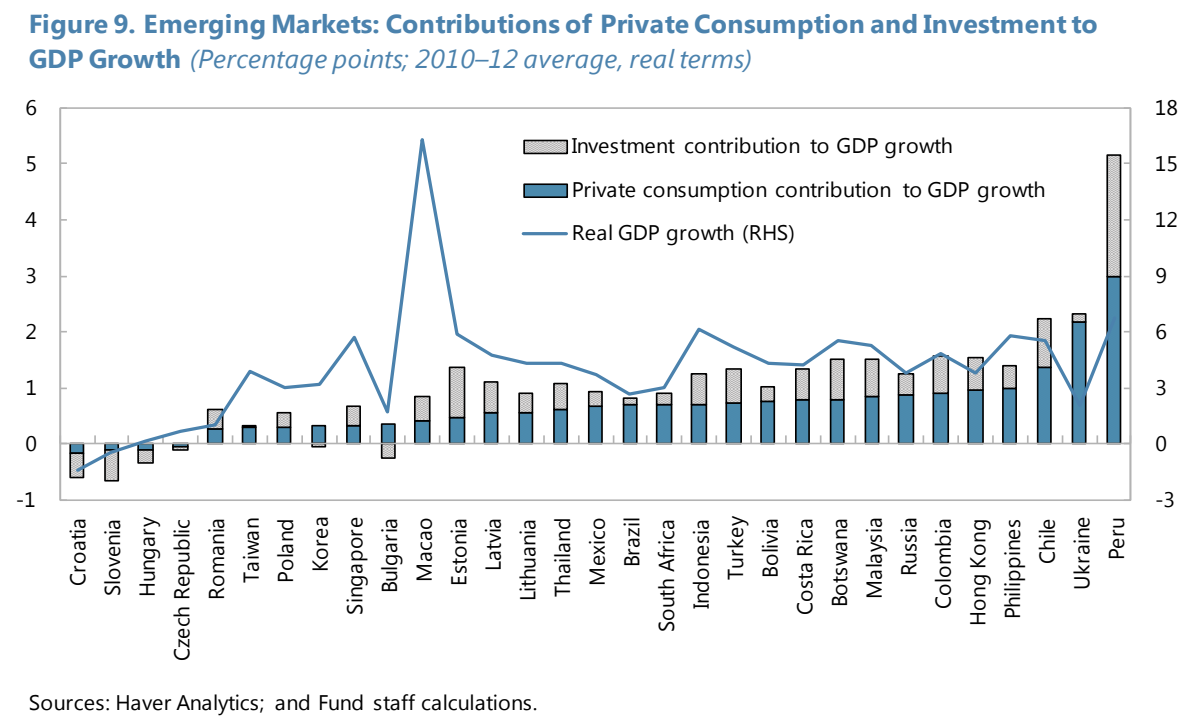

In order to capture the channels through which credit shocks transmit to economic growth, we choose the consumption (or investment) contribution to real GDP growth as our dependent variable. In a similar way, we can decompose the total credit growth into contributions from three components, namely, corporate, consumer, and housing credit as follows. ${ }^{6}$

\footnotetext{
${ }^{4}$ All national account and credit variables considered in this paper are expressed in real terms.

${ }^{5}$ The contribution of private consumption to real GDP growth (in the following denoted as consumption contribution to GDP growth) is calculated as (private consumption - private consumption $_{t-1}$ ) $/ G D P_{t-1}$, all in real terms. The contribution of private investment to GDP growth (denoted as investment contribution to GDP growth) is calculated in a similar way.

${ }^{6}$ A chart of the three types of contributions to credit growth is shown in the introduction section.
} 


$$
\begin{aligned}
& \frac{\text { Credit }_{t}^{\text {Total }}-\text { Credit }_{t-1}^{\text {Total }}}{\text { Credit }_{t-1}^{\text {Total }}} \\
& =\frac{\text { Credit }_{t}^{\text {Corporate }}-\text { Credit }_{t-1}^{\text {Corporate }}}{\text { Credit }_{t-1}^{\text {Total }}} \\
& +\frac{\text { Credit }_{t}^{\text {Consumer }}-\text { Credit }_{t-1}^{\text {Consumer }}}{\text { Credit }_{t-1}^{\text {Total }}} \\
& +\frac{\text { Credit }_{t}^{\text {Housing }}-\text { Credit }_{t-1}^{\text {Housing }}}{\text { Credit }_{t-1}^{\text {Total }}}
\end{aligned}
$$

The three items on the right-hand side of the equation will be referred to, henceforth, as corporate contribution, consumer contribution, and housing contribution to credit growth, respectively. We favor the use of contributions rather than growth rates for the credit variables in other to avoid using a distorted measure of the expansion of certain types of credit for the purposes of their impact on economic activity. This is the case, for example, with housing credit (or mortgages), which has been growing rapidly in some EMs, yet the share of housing credit in total credit in a few of these countries is still small, particularly in Brazil.

In particular, our baseline specification is:

$$
\begin{aligned}
C_{i t}= & \alpha_{0}+\alpha_{1} \cdot \text { Credit }_{i t}^{\text {Corporate }}+\alpha_{2} \cdot \text { Credit }_{\text {it }}^{\text {Consumer }}+\alpha_{3} \cdot \text { Credit }_{i t}^{\text {Housing }}+\alpha_{4} \cdot X_{i t}+\alpha_{5} \cdot Z_{t}+ \\
& \varepsilon_{i t}
\end{aligned}
$$

where $i$ and $t$ refer to country and time (in quarters), respectively. $C_{i t}$ is the contribution of private consumption to real GDP growth. $X_{i t}$ is domestic control variables including domestic short-term interest rate, real effective exchange rate, corporate issuances of bonds, equities and loans (in real terms), and government consumption growth. $Z_{t}$ denotes global controls including OECD real GDP growth, global interest rate, and VIX. Credit ${ }_{i t}^{\text {Corporate }}$, Credit $_{i t}^{\text {Consumer }}$, and Credit ${ }_{i t}^{\text {Housing }}$ are the contributions of corporate, consumer, and housing credit to total credit growth, respectively. The change in domestic short-term interest rate is included to capture the effects of interest rate policy on growth through channels other than bank lending. We also include corporate issuances of bonds, equities and loans (deflated by $\mathrm{CPI}$ ) as an explanatory variable to control for the non-bank sources of financing. The growth of government consumption serves as a measure of fiscal stimulus. The change in the three-month London interbank offered rates (LIBOR) is used to capture global liquidity and funding cost for the corporate sector. Finally, VIX measures the global risk aversion. ${ }^{7}$

\footnotetext{
${ }^{7}$ The set of global controls help capture that global conditions are different in the period after the global financial crisis. Future work could explore if the sensitivity of real GDP growth, our dependent variable, to domestic credit growth has changed since then.
} 
The coefficients of interest are $\alpha_{1}, \alpha_{2}$, and $\alpha_{3}$. A similar specification but with investment contribution to real GDP growth as dependent variable is also estimated to capture the impact of credit on economic activity through the investment channel. Since private investment is not available for most EMs in our sample, we use the contribution of total investment to real GDP growth as the dependent variable.

Our sample is a quarterly panel consisting of $31 \mathrm{EMs}$ over the period 2002:Q1-2012:Q4. ${ }^{8}$ It spreads over 9 Asian EMs, 7 Latin American EMs, 13 European EMs, and 2 African EMs. Appendix I provides the list of the countries in the sample and a detailed description of the variables in our regressions. For countries with bank lending being provided by both private and public financial institutions, such as in Brazil, credit variables include total loans, regardless of the ownership of the lender.

\section{Results}

The estimation results of the cross-country dynamic panel model (2) are presented in Appendix II. Different estimation methods are used to estimate the baseline model (2).

Panel A of Appendix II presents the results with the dependent variable of the contribution of private consumption to real GDP growth, using various estimation methods including the pooled ordinary least squares (OLS), OLS with (cross-section) fixed effects, pooled two-stage least squares (2SLS), 2SLS with (cross-section) fixed effects, and Arellano-Bond dynamic generalized method of moments (GMM). The 2SLS and Arellano-Bond GMM estimators are used to deal with the endogeneity of credit variables. The instruments used in the 2SLS and GMM estimations include the first- and second-order lags of global variables as well as their contemporaneous values, the first- and second-order lags of the credit variables (i.e. consumer, corporate, and housing contribution to credit growth), and the second-order lags of the dependent variable and domestic control variables. ${ }^{9}$ The $J$-statistics for the $J$-test of over-identifying restrictions indicate that the null hypothesis that the over-identifying restrictions are valid cannot be rejected, suggesting that these instruments are likely to be valid.

Panel B of Appendix II presents the estimation results with the contribution of investment to real GDP growth as the dependent variable. Finally, since most of the explanatory domestic variables are endogenous, the OLS estimates are likely to be biased. Furthremore, due to the dynamic panel bias, the estimates from the Arellano-Bond dynamic GMM estimator could be more reliable.

Two alternative specifications slightly different from model (2) are also estimated using all the estimation methods in order to check the robustness of the results. The alternative specifications try to directly capture the lagged impact of domestic monetary policy on economic growth. Thus, in the alternative specifications, we either replace the change in

\footnotetext{
${ }^{8}$ The sample is an unbalance panel, and the time spans for different countries depend on their data availability.

${ }^{9}$ The first-order lags of the dependent variable and domestic control variables are most likely to be endogenous as well because the dependent variable contains a component of the lagged real GDP.
} 
domestic short-term interest rate in model (2) by the lagged change in interest rate, or simply add the lagged change in interest rate to model (2).

The main findings of the estimations are simply illustrated in Table 1. These results suggest that for the 31 EMs in our sample, consumer and corporate credit growth have significantly positive effects on real GDP growth through the consumption and investment channels, respectively. These findings, in line with most empirical literature such as Ludvigson (1999) and Brigden and Mizen (1999), seem to suggest the existence of credit channels in supporting economic growth in our sample EM countries. In addition, housing credit seems to also matter for economic growth through the consumption channel in two out of the three specifications, suggesting that mortgage is also likely to play a role in driving consumption growth in the sample EMs. This finding is consistent with a positive wealth effect of house prices on household spending, as documented by Campbell and Cocco (2007). Rising house prices could stimulate consumption by increasing households' perceived wealth or by relaxing borrowing constraints. In addition, Mian and Sufi (2014) find that, as part of mortgage loans, cash-out refinancing mortgage in response to house price growth has a large impact on household spending.

Table 1. Summary of Main Results

\begin{tabular}{lccc}
\hline Dependent Variable & Corporate Credit & Consumer Credit & Housing Credit \\
\hline $\begin{array}{l}\text { Contribution of Private } \\
\text { Consumption to real GDP Growth }\end{array}$ & $* * *$ & $* *$ \\
Contribution of Investment to real & $* * *$ & \\
GDP Growth & & \\
\hline
\end{tabular}

Note: $* * *$ indicates statistical significance at the $5 \%$ level across all three specifications using the Arellano-Bond dynamic GMM estimator. ** indicates statistical significance at the $5 \%$ level for two out of the three specifications using the ArellanoBond dynamic GMM estimator.

The GMM-estimated coefficients in Panels A and B of Appendix II suggest that, for the average EM economy, one standard-deviation shocks to consumer and corporate credit seem to generate similar effects on real GDP growth. More specifically, a one standard-deviation shock to the consumer credit (in terms of contribution to credit growth) is about 4 percentage points, and is likely to increase the real GDP growth by 0.3 percentage points. At the same time, a one standard-deviation increase in the corporate credit (in terms of contribution to credit growth) is about 10 percentage points, and can raise the real GDP growth by about 0.3 percentage points as well. In other words, since consumption is less volatile than investment, a one-percentage-point increase in the consumer credit has a larger impact on economic growth than that of the corporate credit. One explanation for the relatively small impact of corporate credit on growth is that during certain periods corporates may prefer to use part of the loan proceeds to build-up cash cushions. For example, when funding is cheap, companies may decide to build-up their cash positions as pre-financing for expected future capital outlays. An alternative explanation for raising cash holdings is that borrowing may help strengthen corporates' liquidity position and therefore their resilience to financial shocks. 
In addition, the change in domestic short-term interest rate has a significantly negative impact on the private consumption contribution to real GDP growth, implying an increased saving of households due to the increase in interest rate. However, as one would expect, after controlling for the corporate credit and capital market issuances, the change in interest rate does not have any significant impact on the investment contribution to real GDP growth.

The growth of government consumption has a significantly negative impact on the private consumption contribution and a significantly positive impact on the investment contribution. This former finding is in line with the predictions of theoretical models by Aiyagari et al. (1992) and Baxter and King (1993) that increases in government spending significantly lead to a decline in private consumption, although some empirical literature seems to find a crowding-in effect rather than a crowding-out effect (Karras, 1994). The latter finding is consistent with some empirical studies such as Ahmed and Miller (2000) who argue that government spending on the transportation and communication sectors can effectively induce private investment. However, some other studies argue that public consumption crowds out private investment. Ploeg (2005) presents a model which shows that cutting public employment - a major item in the budget - leads to lower wages, a rise in private employment, and a boost in investment. His work assumes perfect substitutability between private and public provision of goods. Alesina et al (2002) also finds, using data for OECD countries, that increases in the government wage bill increase labor costs, and reduce profits and investment.

Capital market issuances seem to also have a significant positive impact on the investment contribution but not on the private consumption contribution, underscoring the importance of capital market financing for the corporate sector of the sample EMs. Finally, the OECD real GDP growth also has a significantly positive impact on the investment contribution but not the private consumption contribution. This could be due to the stimulus of increased exports (resulting from a higher external demand) on firms' investment.

\section{Case Study: Brazil}

This section examines the case of credit in Brazil, which expanded rapidly during the past decade. More recently, credit growth has persistently decelerated. A downturn phase of the credit cycle started in early 2013 driven by a slowdown in credit expansion by public banks, while private bank credit continued to expand at a moderate pace.

During the period of robust credit expansion, macroeconomic stability and financial inclusion on the back of real income gains and robust employment seem to have been the key drivers of increased demand for consumer credit in Brazil. Institutional improvements and new instruments also favored the supply of credit to households, for example, fiduciary assignments on housing and auto loans and payroll deducted personal loans. As a result of a decade of strong credit growth, credit in Brazil reached about 50 percent of GDP by end-2012 (up from 24 percent in 2002), above the average in Latin America but still below the average in other emerging markets. 
During that period, output also grew rapidly in Brazil. Real GDP growth averaged nearly 2 percent during the period 1996-2003, while credit expanded at an average of 1.5 percent in real terms. During 2004-08, average GDP growth rose to 4.8 percent and credit accelerated to average annual real rates of 19 percent. Since 2010, real GDP growth and credit moderated to $33 / 4$ percent and 12 percent, respectively.

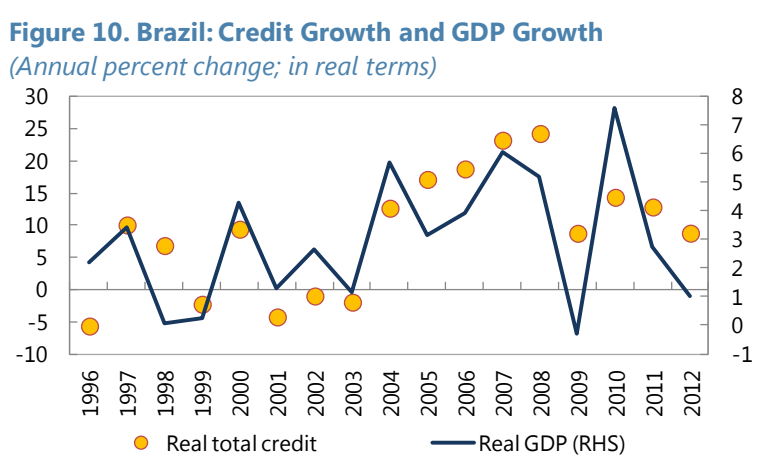

Sources: Central Bank of Brazil; and Haver Analytics.

A Brazil-specific VAR model with exogenous variables (VARX) is built and estimated to better focus on the effects of credit composition on GDP growth in Brazil. ${ }^{10}$

$$
Y_{t}^{\text {Brazil }}=A(L) Y_{t}^{\text {Brazil }}+B_{1} X_{t}^{\text {Brazil }}+B_{2} Z_{t}+\epsilon_{t}^{\text {Brazil }}
$$

where $Y_{t}^{\text {Brazil }}$ denotes endogenous variables including the credit and dependent variables in the panel regressions, namely, corporate, consumer and housing contributions to credit growth, and consumption and investment contributions to real GDP growth. $X_{t}^{\text {Brazil }}$ and $Z_{t}$ are the domestic and global control variables as in the cross-country panel regressions presented above. ${ }^{11}$ Cholesky decomposition is used to identify the six structural shocks, namely, shocks to corporate, consumer, and housing credit, and other shocks to the consumption and investment contributions to real GDP growth. The Cholesky ordering of credit variables is chosen as the same ordering of the variables in $Y_{t}^{\text {Brazil }}$. Different Cholesky orderings do not alter the qualitative results.

Appendix III presents the impulse response functions of Brazil's consumption, investment, and GDP growth to the three types of shocks to credit. The cumulative impulse response functions of the VARX model suggest that, shocks to both consumer and corporate credit are likely to increase real GDP growth significantly (Appendix III. Figure). Three points are worth noticing. First, consumer credit has a significant impact on the contribution of consumption to real GDP growth, while corporate credit has a significant impact on the contribution of investment to real GDP growth. Second, the peak impact of a consumer credit shock on consumption contribution happens simultaneously with the shock, while the peak impact of a corporate credit shock on investment contribution happens in two quarters after the shock. Third, the estimated impulse responses of one standard-deviation shocks to consumer and corporate credit on the real GDP growth are not significantly different from each other at the peak. Based on the estimated coefficients, we can also quantitatively

\footnotetext{
${ }^{10}$ A system of equations in the VAR could also help us identify the channels through which credit shocks take effect.

${ }^{11} \mathrm{We}$ also include the international commodity price as a global variable in the Brazil VARX although this variable was not included in the cross-country panel regressions. The reason is that the panel sample comprises both commodity exporters and importers. The domestic and global control variables are assumed to be exogenous in the VAR.
} 
measure the cumulative impact of the growth of consumer and corporate credit on real GDP growth. ${ }^{12}$ In particular, a one-standard-deviation shock to the (quarter-on-quarter) growth rate of Brazil's consumer credit (about 2.6 percentage points) is likely to increase real GDP growth by about 0.2 percentage points over a year after the shock. Similarly, a one-standard-deviation increase in the (quarter-on-quarter) growth rate of corporate credit (about 2.9 percentage points) can raise the real GDP growth rate by about 0.1 percentage points over a year after the shock. ${ }^{13}$

\section{CONCLUding ReMARKS}

This paper has found that credit growth and its composition (i.e. corporate, consumer, and housing credit) had significant impact on economic growth in EMs during the past decade. The cross-country panel regressions with a sample of 31 EMs and various estimators suggest that credit expansion and the composition of credit growth matter for economic growth. The estimators include pooled OLS, fixed-effect OLS, pooled 2SLS, fixed-effect 2SLS and Arellano-Bond dynamic GMM. The instrument variables used for 2SLS and GMM mainly include contemporaneous and lagged global variables as well as lagged credit variables and domestic control variables, which successfully pass the $J$-test for over-identifying restrictions. The estimates suggest that the magnitude and transmission channel of the impact of credit on real activity depend on the specific type of credit growth. In particular, we find that shocks to corporate and consumer credit tend to operate through different transmission channels. Corporate credit shocks influence economic growth mainly through investment, while consumer credit shocks are more associated with private consumption. Furthermore, housing credit shocks seem to also have some positive impact on economic growth through the consumption channel, although the impact is only significant in two out of three model specifications. These findings are consistent with other empirical studies such as Brigden and Mizen (1999), Ludvigson (1999), and Mian and Sufi (2014). The time-series case study for Brazil yields similar conclusions.

In addition, we find that corporate credit shocks, which operate through the investment channel, tend to have smaller effects on GDP growth than consumer credit shocks. A possible explanation for this finding is that corporates may use part of the loan proceeds to build-up cash cushions, especially when funding is cheap or when they see a need to strengthen their liquidity position. Testing this hypothesis could be the focus of future research.

These findings might shed some light on explaining the different growth modelsconsumption or investment-led growth - we observe across EMs. More importantly, policy implications may follow as countries aim to foster growth, and in particular, long-term

\footnotetext{
${ }^{12}$ Here we are quantitatively measuring the impact of the shocks to the growth rates of consumer and corporate credit instead of the corporate contribution to credit growth (as considered in the cross-country panel regressions). All the figures presented below are annualized peak impact.

${ }^{13}$ However, the effects of one-standard-deviation shocks to the growth rates of consumer and corporate credit are not significantly different from each other.
} 
growth. A range of banking sector prudential tools - such as tightening or loosening loan eligibility criteria, asset concentration and credit growth for certain credit portfolios-could be used to achieve a desired balance in the credit composition. 


\begin{abstract}
APPENDiX I. DATA
The sample includes 31 emerging markets (EMs) over the period 2002:Q1-2012:Q4, covering 9 Asian EMs, 7 Latin American EMs, 13 European EMs, and 2 African EMs: Brazil, Bolivia, Botswana, Bulgaria, Chile, Colombia, Costa Rica, Croatia, Czech Republic, Estonia, Hong Kong, Hungary, Indonesia, Latvia, Lithuania, Macao, Malaysia, Mexico, Peru, Philippines, Poland, Romania, Russia, Singapore, Slovenia, South Africa, South Korea, Taiwan, Thailand, Turkey, and Ukraine. Time span varies depending on countries' data availability of bank lending, particularly the composition of bank lending.

Variables are defined as follows:

- Short-term interest rate is the policy rate in most countries as long as it is available. For countries where no policy rate is available, we use deposit rates. The data come from Haver analytics.

- Real effective exchange rate is based on consumer price index and taken from the Information Notification System (INS) of the IMF.

- Corporate issuances of bonds, equities and loans are defined in percent of GDP, and are taken from the Dealogic database.

- Government consumption is taken from Haver analytics.

- OECD real GDP (a measure of global demand), international commodity prices, and LIBOR (a measure of global liquidity) are obtained from the IMF's International Financial Statistics (IFS) database.

- The Chicago Board Options Exchange Market Volatility Index (VIX), a measure of global risk aversion, is taken from Bloomberg database.

- Nominal credit variables comprise different types of bank lending to the private sector obtained from countries' central banks, Haver analytics, and dXtime database. These nominal credit variables are then deflated by CPI (obtained from Haver analytics) to calculate the real credit variables.
\end{abstract}


Appendix II. Cross-Country Dynamic Panel Regressions Results

\begin{tabular}{|c|c|c|c|c|c|c|c|c|c|c|c|c|c|c|c|}
\hline \multicolumn{16}{|c|}{ Panel A. Cross-country dynamic panel regressions for the contribution of consumption to real GDP growth } \\
\hline $\begin{array}{l}\text { Dependent } \\
\text { variable }\end{array}$ & Contributi & of private $\mathrm{c}$ & sumption to & eal GDP gro & & & & & & & & & & & \\
\hline \multirow[t]{2}{*}{$\begin{array}{l}\text { Estimation } \\
\text { method }\end{array}$} & $\begin{array}{l}\text { OLS } \\
\text { (Pooled) }\end{array}$ & $\begin{array}{l}\text { OLS } \\
\text { (Pooled) }\end{array}$ & $\begin{array}{l}\text { OLS } \\
\text { (Pooled) }\end{array}$ & $\begin{array}{l}\text { OLS } \\
(\mathrm{FE})\end{array}$ & $\begin{array}{l}\text { OLS } \\
\text { (FE) }\end{array}$ & $\begin{array}{l}\text { OLS } \\
(\mathrm{FE})\end{array}$ & $\begin{array}{l}\text { 2SLS } \\
\text { (Pooled) }\end{array}$ & $\begin{array}{l}\text { 2SLS } \\
\text { (Pooled) }\end{array}$ & $\begin{array}{l}\text { 2SLS } \\
\text { (Pooled) }\end{array}$ & $\begin{array}{l}\text { 2SLS } \\
\text { (FE) }\end{array}$ & $\begin{array}{l}\text { 2SLS } \\
\text { (FE) }\end{array}$ & $\begin{array}{l}\text { 2SLS } \\
\text { (FE) }\end{array}$ & $\begin{array}{l}\text { GMM } \\
\text { (Arellano- } \\
\text { Bond) }\end{array}$ & $\begin{array}{l}\text { GMM } \\
\text { (Arellano- } \\
\text { Bond) }\end{array}$ & $\begin{array}{l}\text { GMM } \\
\text { (Arellano- } \\
\text { Bond) }\end{array}$ \\
\hline & $(1)$ & (2) & (3) & (1) & (2) & (3) & (1) & (2) & (3) & (1) & (2) & (3) & (1) & (2) & (3) \\
\hline Constant & $\begin{array}{l}0.13 \\
(0.12)\end{array}$ & $\begin{array}{l}0.19 \\
(0.12)\end{array}$ & $\begin{array}{l}0.13 \\
(0.13)\end{array}$ & $\begin{array}{l}0.21 \\
(0.15)\end{array}$ & $\begin{array}{l}0.28 \\
(0.15)\end{array}$ & $\begin{array}{l}0.21 \\
(0.16)\end{array}$ & $\begin{array}{l}-0.04 \\
(0.18)\end{array}$ & $\begin{array}{l}-0.11 \\
(0.18)\end{array}$ & $\begin{array}{l}-0.08 \\
(0.19)\end{array}$ & $\begin{array}{l}0.07 \\
(0.13)\end{array}$ & $\begin{array}{l}-0.005 \\
(0.15)\end{array}$ & $\begin{array}{l}0.01 \\
(0.17)\end{array}$ & & & \\
\hline $\begin{array}{l}\text { Corporate } \\
\text { credit }\end{array}$ & $\begin{array}{l}0.016^{* * *} \\
(0.005)\end{array}$ & $\begin{array}{l}0.016^{* * *} \\
(0.004)\end{array}$ & $\begin{array}{l}0.017^{* * *} \\
(0.005)\end{array}$ & $\begin{array}{l}0.014 * * * \\
(0.004)\end{array}$ & $\begin{array}{l}0.014 * * * \\
(0.004)\end{array}$ & $\begin{array}{l}0.016^{* * *} \\
(0.004)\end{array}$ & $\begin{array}{l}-0.01 \\
(0.02)\end{array}$ & $\begin{array}{l}-0.01 \\
(0.02)\end{array}$ & $\begin{array}{l}-0.02 \\
(0.03)\end{array}$ & $\begin{array}{l}-0.02 \\
(0.03)\end{array}$ & $\begin{array}{l}-0.01 \\
(0.03)\end{array}$ & $\begin{array}{l}-0.03 \\
(0.04)\end{array}$ & $\begin{array}{l}0.01 \\
(0.01)\end{array}$ & $\begin{array}{l}0.01 \\
(0.01)\end{array}$ & $\begin{array}{l}0.02 \\
(0.02)\end{array}$ \\
\hline $\begin{array}{l}\text { Consumer } \\
\text { credit }\end{array}$ & $\begin{array}{l}0.02 \\
(0.01)\end{array}$ & $\begin{array}{l}0.02 \\
(0.01)\end{array}$ & $\begin{array}{l}0.02 \\
(0.01)\end{array}$ & $\begin{array}{l}0.016 \\
(0.014)\end{array}$ & $\begin{array}{l}0.01 \\
(0.01)\end{array}$ & $\begin{array}{l}0.02 \\
(0.01)\end{array}$ & $\begin{array}{l}0.11^{* *} \\
(0.05)\end{array}$ & $\begin{array}{l}0.10^{* *} \\
(0.05)\end{array}$ & $\begin{array}{l}0.11 * * \\
(0.06)\end{array}$ & $\begin{array}{l}0.11 \\
(0.07)\end{array}$ & $\begin{array}{l}0.10^{*} \\
(0.06)\end{array}$ & $\begin{array}{l}0.13 \\
(0.09)\end{array}$ & $\begin{array}{l}0.11 * * \\
(0.05)\end{array}$ & $\begin{array}{l}0.03^{*} \\
(0.01)\end{array}$ & $\begin{array}{l}0.10^{*} \\
(0.06)\end{array}$ \\
\hline $\begin{array}{l}\text { Housing } \\
\text { credit }\end{array}$ & $\begin{array}{l}0.02 * \\
(0.01)\end{array}$ & $\begin{array}{l}0.02 \\
(0.01)\end{array}$ & $\begin{array}{l}0.02 * \\
(0.01)\end{array}$ & $\begin{array}{l}0.03 * * * \\
(0.01)\end{array}$ & $\begin{array}{l}0.03 * * * \\
(0.01)\end{array}$ & $\begin{array}{l}0.03^{* * * *} \\
(0.01)\end{array}$ & $\begin{array}{l}0.02 \\
(0.02)\end{array}$ & $\begin{array}{l}0.01 \\
(0.02)\end{array}$ & $\begin{array}{l}0.02 \\
(0.02)\end{array}$ & $\begin{array}{l}0.04 \\
(0.03)\end{array}$ & $\begin{array}{l}0.03 \\
(0.04)\end{array}$ & $\begin{array}{l}0.05 \\
(0.04)\end{array}$ & $\begin{array}{l}0.17 * * \\
(0.07)\end{array}$ & $\begin{array}{l}-0.03 \\
(0.02)\end{array}$ & $\begin{array}{l}0.21 * * * \\
(0.07)\end{array}$ \\
\hline$\Delta($ Interest rate $)$ & $\begin{array}{l}-0.02 * * \\
(0.01)\end{array}$ & & $\begin{array}{l}-0.023^{* * *} \\
(0.008)\end{array}$ & $\begin{array}{l}-0.02 * * \\
(0.01)\end{array}$ & & $\begin{array}{l}-0.03^{* * *} \\
(0.01)\end{array}$ & $\begin{array}{l}0.05 \\
(0.04)\end{array}$ & & $\begin{array}{l}0.03 \\
(0.03)\end{array}$ & $\begin{array}{l}0.05 \\
(0.04)\end{array}$ & & $\begin{array}{l}0.04 \\
(0.04)\end{array}$ & $\begin{array}{l}-0.10 * * \\
(0.05)\end{array}$ & & $\begin{array}{l}-0.14 * * \\
(0.07)\end{array}$ \\
\hline$\Delta(\text { Interest rate })_{t-1}$ & & $\begin{array}{l}-0.003 \\
(0.01)\end{array}$ & $\begin{array}{l}-0.01 \\
(0.01)\end{array}$ & & $\begin{array}{l}-0.005 \\
(0.01)\end{array}$ & $\begin{array}{l}-0.01 \\
(0.01)\end{array}$ & & $\begin{array}{l}-0.03 \\
(0.03)\end{array}$ & $\begin{array}{l}-0.03 \\
(0.02)\end{array}$ & & $\begin{array}{l}-0.03 \\
(0.03)\end{array}$ & $\begin{array}{l}-0.03 \\
(0.03)\end{array}$ & & $\begin{array}{l}0.003 \\
(0.007)\end{array}$ & $\begin{array}{l}-0.02 \\
(0.01)\end{array}$ \\
\hline$\Delta \log ($ REER $)$ & $\begin{array}{l}0.02 * \\
(0.01)\end{array}$ & $\begin{array}{l}0.01 \\
(0.01)\end{array}$ & $\begin{array}{l}0.02 * \\
(0.01)\end{array}$ & $\begin{array}{l}0.02 * * \\
(0.01)\end{array}$ & $\begin{array}{l}0.01 \\
(0.01)\end{array}$ & $\begin{array}{l}0.015^{*} \\
(0.008)\end{array}$ & $\begin{array}{l}0.01 \\
(0.07)\end{array}$ & $\begin{array}{l}0.01 \\
(0.06)\end{array}$ & $\begin{array}{l}-0.01 \\
(0.06)\end{array}$ & $\begin{array}{l}-0.03 \\
(0.06)\end{array}$ & $\begin{array}{l}-0.02 \\
(0.05)\end{array}$ & $\begin{array}{l}-0.04 \\
(0.06)\end{array}$ & $\begin{array}{l}0.06 \\
(0.07)\end{array}$ & $\begin{array}{l}0.02 \\
(0.03)\end{array}$ & $\begin{array}{l}0.06 \\
(0.07)\end{array}$ \\
\hline $\begin{array}{l}\Delta \log (\text { Government } \\
\text { consumption })\end{array}$ & $\begin{array}{l}0.003 * \\
(0.002)\end{array}$ & $\begin{array}{l}0.003 * \\
(0.001)\end{array}$ & $\begin{array}{l}0.003^{*} \\
(0.002)\end{array}$ & $\begin{array}{l}0.003 * * \\
(0.001)\end{array}$ & $\begin{array}{l}0.003 * * \\
(0.001)\end{array}$ & $\begin{array}{l}0.003 * * \\
(0.001)\end{array}$ & $\begin{array}{l}-0.02 * * * \\
(0.004)\end{array}$ & $\begin{array}{l}-0.019 * * * \\
(0.004)\end{array}$ & $\begin{array}{l}-0.021 * * * \\
(0.005)\end{array}$ & $\begin{array}{l}-0.017 * * * \\
(0.004)\end{array}$ & $\begin{array}{l}-0.017 * * * \\
(0.004)\end{array}$ & $\begin{array}{l}-0.020 * * * \\
(0.005)\end{array}$ & $\begin{array}{l}-0.013 * * * \\
(0.002)\end{array}$ & $\begin{array}{l}-0.03^{* * *} \\
(0.01)\end{array}$ & $\begin{array}{l}-0.013 * * * \\
(0.001)\end{array}$ \\
\hline $\begin{array}{l}\text { Issuances of bonds, } \\
\text { equities, and loans }\end{array}$ & $\begin{array}{l}-0.002 \\
(0.002)\end{array}$ & $\begin{array}{l}-0.002 \\
(0.002)\end{array}$ & $\begin{array}{l}-0.002 \\
(0.002)\end{array}$ & $\begin{array}{l}0.006^{*} \\
(0.003)\end{array}$ & $\begin{array}{l}0.005 \\
(0.004)\end{array}$ & $\begin{array}{l}0.005 \\
(0.004)\end{array}$ & $\begin{array}{l}-0.005 \\
(0.006)\end{array}$ & $\begin{array}{l}-0.01 \\
(0.01)\end{array}$ & $\begin{array}{l}-0.005 \\
(0.006)\end{array}$ & $\begin{array}{l}0.01 \\
(0.01)\end{array}$ & $\begin{array}{l}0.006 \\
(0.008)\end{array}$ & $\begin{array}{l}0.01 \\
(0.01)\end{array}$ & $\begin{array}{l}0.01 \\
(0.02)\end{array}$ & $\begin{array}{l}-0.04 * * \\
(0.02)\end{array}$ & $\begin{array}{l}0.02 \\
(0.03)\end{array}$ \\
\hline $\begin{array}{l}\Delta \log (\mathrm{OECD} \\
\text { GDP })\end{array}$ & $\begin{array}{l}0.12 * * * \\
(0.02)\end{array}$ & $\begin{array}{l}0.12^{* * *} \\
(0.02)\end{array}$ & $\begin{array}{l}0.11 * * * \\
(0.02)\end{array}$ & $\begin{array}{l}0.12 * * * \\
(0.02)\end{array}$ & $\begin{array}{l}0.12^{* * *} \\
(0.03)\end{array}$ & $\begin{array}{l}0.11^{* * *} \\
(0.03)\end{array}$ & $\begin{array}{l}0.12 * * * \\
(0.03)\end{array}$ & $\begin{array}{l}0.10^{* * *} \\
(0.03)\end{array}$ & $\begin{array}{l}0.10^{* * *} \\
(0.03)\end{array}$ & $\begin{array}{l}0.13^{* * *} \\
(0.03)\end{array}$ & $\begin{array}{l}0.11 * * * \\
(0.02)\end{array}$ & $\begin{array}{l}0.12^{* * *} \\
(0.03)\end{array}$ & $\begin{array}{l}0.03 \\
(0.05)\end{array}$ & $\begin{array}{l}0.11 * * * \\
(0.02)\end{array}$ & $\begin{array}{l}0.03 \\
(0.05)\end{array}$ \\
\hline$\Delta \mathrm{LIBOR}$ & $\begin{array}{l}0.04 \\
(0.18)\end{array}$ & $\begin{array}{l}0.004 \\
(0.17)\end{array}$ & $\begin{array}{l}0.06 \\
(0.17)\end{array}$ & $\begin{array}{l}0.04 \\
(0.21)\end{array}$ & $\begin{array}{l}0.003 \\
(0.19)\end{array}$ & $\begin{array}{l}0.06 \\
(0.20)\end{array}$ & $\begin{array}{l}-0.02 \\
(0.14)\end{array}$ & $\begin{array}{l}0.11 \\
(0.09)\end{array}$ & $\begin{array}{l}0.06 \\
(0.11)\end{array}$ & $\begin{array}{l}-0.05 \\
(0.13)\end{array}$ & $\begin{array}{l}0.09 \\
(0.09)\end{array}$ & $\begin{array}{l}0.02 \\
(0.11)\end{array}$ & $\begin{array}{l}0.19^{*} \\
(0.11)\end{array}$ & $\begin{array}{l}0.10 \\
(0.12)\end{array}$ & $\begin{array}{l}0.21 * * \\
(0.10)\end{array}$ \\
\hline VIX & $\begin{array}{l}0.001 \\
(0.004)\end{array}$ & $\begin{array}{l}-0.002 \\
(0.004)\end{array}$ & $\begin{array}{l}0.001 \\
(0.004)\end{array}$ & $\begin{array}{l}-0.002 \\
(0.005)\end{array}$ & $\begin{array}{l}-0.004 \\
(0.005)\end{array}$ & $\begin{array}{l}-0.001 \\
(0.005)\end{array}$ & $\begin{array}{l}0.005 \\
(0.007)\end{array}$ & $\begin{array}{l}0.01^{*} \\
(0.006)\end{array}$ & $\begin{array}{l}0.008 \\
(0.006)\end{array}$ & $\begin{array}{l}0.000 \\
(0.005)\end{array}$ & $\begin{array}{l}0.01 \\
(0.01)\end{array}$ & $\begin{array}{l}0.004 \\
(0.005)\end{array}$ & $\begin{array}{l}0.01 \\
(0.01)\end{array}$ & $\begin{array}{l}-0.005^{*} \\
(0.003)\end{array}$ & $\begin{array}{l}0.02 \\
(0.02)\end{array}$ \\
\hline $\begin{array}{l}\text { Lagged dependent } \\
\text { variable }\end{array}$ & $\begin{array}{l}0.14 * * * \\
(0.06)\end{array}$ & $\begin{array}{l}0.14 * * \\
(0.06)\end{array}$ & $\begin{array}{l}0.14 * * \\
(0.06)\end{array}$ & $\begin{array}{l}0.01 \\
(0.07) \\
\end{array}$ & $\begin{array}{l}0.01 \\
(0.07) \\
\end{array}$ & $\begin{array}{l}0.006 \\
(0.07) \\
\end{array}$ & $\begin{array}{l}0.43 * * * \\
(0.14) \\
\end{array}$ & $\begin{array}{l}0.42 * * * \\
(0.15) \\
\end{array}$ & $\begin{array}{l}0.45^{* * *} \\
(0.13) \\
\end{array}$ & $\begin{array}{l}0.30 * * * \\
(0.10) \\
\end{array}$ & $\begin{array}{l}0.29 * * * \\
(0.10) \\
\end{array}$ & $\begin{array}{l}0.33 * * * \\
(0.11) \\
\end{array}$ & $\begin{array}{l}0.24 * * * \\
(0.06) \\
\end{array}$ & $\begin{array}{l}-0.18 * * * \\
(0.05)\end{array}$ & $\begin{array}{l}0.22 * * * \\
(0.07) \\
\end{array}$ \\
\hline
\end{tabular}




\section{Appendix II. Cross-Country Dynamic Panel Regressions Results (continued)}

\begin{tabular}{|c|c|c|c|c|c|c|c|c|c|c|c|c|c|c|c|}
\hline $\begin{array}{l}\text { Dependent } \\
\text { variable }\end{array}$ & Contribut & of private & isumption & eal GDF & & & & & & & & & & & \\
\hline \multirow[t]{2}{*}{$\begin{array}{l}\text { Estimation } \\
\text { method }\end{array}$} & $\begin{array}{l}\text { OLS } \\
\text { (Pooled) }\end{array}$ & $\begin{array}{l}\text { OLS } \\
\text { (Pooled) }\end{array}$ & $\begin{array}{l}\text { OLS } \\
\text { (Pooled) }\end{array}$ & $\begin{array}{l}\text { OLS } \\
\text { (FE) }\end{array}$ & $\begin{array}{l}\text { OLS } \\
\text { (FE) }\end{array}$ & $\begin{array}{l}\text { OLS } \\
\text { (FE) }\end{array}$ & $\begin{array}{l}\text { 2SLS } \\
\text { (Pooled } \\
\text { ) }\end{array}$ & $\begin{array}{l}\text { 2SLS } \\
\text { (Pooled) }\end{array}$ & $\begin{array}{l}\text { 2SLS } \\
\text { (Pooled) }\end{array}$ & $\begin{array}{l}\text { 2SLS } \\
\text { (FE) }\end{array}$ & $\begin{array}{l}\text { 2SLS } \\
\text { (FE) }\end{array}$ & $\begin{array}{l}\text { 2SLS } \\
(\mathrm{FE})\end{array}$ & $\begin{array}{l}\text { GMM } \\
\text { (Arellano- } \\
\text { Bond) }\end{array}$ & $\begin{array}{l}\text { GMM } \\
\text { (Arellano- } \\
\text { Bond) }\end{array}$ & $\begin{array}{l}\text { GMM } \\
\text { (Arellano } \\
\text {-Bond) }\end{array}$ \\
\hline & (1) & (2) & (3) & (1) & (2) & (3) & (1) & (2) & (3) & (1) & (2) & (3) & (1) & (2) & (3) \\
\hline $\begin{array}{l}\text { Cross-section fixed } \\
\text { effect }\end{array}$ & No & No & No & Yes & Yes & Yes & No & No & Yes & Yes & Yes & Yes & Yes & Yes & Yes \\
\hline Instruments ${ }^{1}$ & No & No & No & No & No & No & Yes & Yes & Yes & Yes & Yes & Yes & Yes & Yes & Yes \\
\hline $\operatorname{Prob}(J$-statistic $)$ & & & & & & & 0.12 & 0.10 & 0.20 & 0.60 & 0.52 & 0.88 & 0.48 & 0.18 & 0.67 \\
\hline Obs. & 1109 & 1094 & 1094 & 1109 & 1094 & 1094 & 1047 & 1047 & 1032 & 1047 & 1047 & 1032 & 1016 & 1016 & 1001 \\
\hline $\operatorname{Adj} . R^{2}$ & 0.18 & 0.18 & 0.18 & 0.27 & 0.27 & 0.28 & -0.22 & -0.15 & -0.26 & -0.10 & -0.03 & -0.22 & & & \\
\hline
\end{tabular}

Note: Robust standard errors are presented in parentheses. Asterisks *, **, $* * *$ indicate statistical significance at the $10 \%, 5 \%$ and $1 \%$ levels, respectively. Corporate/consumer/housing credit is the corresponding contribution to total credit growth. Government consumption is expressed in annualized quarter-on-quarter percent changes. Issuances of bonds, equities, and loans are in real terms, deflated by CPI. Interest rate and Libor are the first-order differences of short-term interest rate and the LIBOR respectively. REER is the first-order difference of the logarithms of real effective exchange rate. Lagged dependent variable is the first lag of the dependent variable.

${ }^{1}$ The instruments for the 2SLS and GMM estimations include the first and second lags of global variables as well as their contemporaneous values, the first and second lags of credit variables, and the second lags of the dependent variable and domestic control variables. 
Appendix II. Cross-Country Dynamic Panel Regressions Results (continued)

\begin{tabular}{|c|c|c|c|c|c|c|c|c|c|c|c|c|c|c|c|}
\hline $\begin{array}{l}\text { Dependent } \\
\text { variable }\end{array}$ & Contribut & of investm & to real GD & rrowth & & & & & & & & & & & \\
\hline \multirow[t]{2}{*}{$\begin{array}{l}\text { Estimation } \\
\text { method }\end{array}$} & $\begin{array}{l}\text { OLS } \\
\text { (Pooled) }\end{array}$ & $\begin{array}{l}\text { OLS } \\
\text { (Pooled) }\end{array}$ & $\begin{array}{l}\text { OLS } \\
\text { (Pooled) }\end{array}$ & $\begin{array}{l}\text { OLS } \\
(\mathrm{FE})\end{array}$ & $\begin{array}{l}\text { OLS } \\
(\mathrm{FE})\end{array}$ & $\begin{array}{l}\text { OLS } \\
(\mathrm{FE})\end{array}$ & $\begin{array}{l}\text { 2SLS } \\
\text { (Pooled) }\end{array}$ & $\begin{array}{l}\text { 2SLS } \\
\text { (Pooled) }\end{array}$ & $\begin{array}{l}\text { 2SLS } \\
\text { (Pooled) }\end{array}$ & $\begin{array}{l}\text { 2SLS } \\
\text { (FE) }\end{array}$ & $\begin{array}{l}\text { 2SLS } \\
\text { (FE) }\end{array}$ & $\begin{array}{l}\text { 2SLS } \\
\text { (FE) }\end{array}$ & $\begin{array}{l}\text { GMM } \\
\text { (Arellano- } \\
\text { Bond) }\end{array}$ & $\begin{array}{l}\text { GMM } \\
\text { (Arellano- } \\
\text { Bond) }\end{array}$ & $\begin{array}{l}\text { GMM } \\
\text { (Arellano- } \\
\text { Bond) }\end{array}$ \\
\hline & (1) & (2) & (3) & (1) & (2) & (3) & (1) & (2) & (3) & (1) & (2) & (3) & (1) & (2) & (3) \\
\hline Constant & $\begin{array}{l}-0.07 \\
(0.13)\end{array}$ & $\begin{array}{l}-0.08 \\
(0.13)\end{array}$ & $\begin{array}{l}-0.11 \\
(0.15)\end{array}$ & $\begin{array}{l}-0.06 \\
(0.14)\end{array}$ & $\begin{array}{l}-0.08 \\
(0.13)\end{array}$ & $\begin{array}{l}-0.10 \\
(0.16)\end{array}$ & $\begin{array}{l}-0.11 \\
(0.18)\end{array}$ & $\begin{array}{l}-0.12 \\
(0.19)\end{array}$ & $\begin{array}{l}-0.09 \\
(0.19)\end{array}$ & $\begin{array}{l}-0.17 \\
(0.21)\end{array}$ & $\begin{array}{l}-0.17 \\
(0.22)\end{array}$ & $\begin{array}{l}-0.15 \\
(0.22)\end{array}$ & & & \\
\hline $\begin{array}{l}\text { Corporate } \\
\text { credit }\end{array}$ & $\begin{array}{l}0.013 * * \\
(0.006)\end{array}$ & $\begin{array}{l}0.013 * * \\
(0.006)\end{array}$ & $\begin{array}{l}0.013^{* *} \\
(0.006)\end{array}$ & $\begin{array}{l}0.013 * * \\
(0.007)\end{array}$ & $\begin{array}{l}0.013 * * \\
(0.006)\end{array}$ & $\begin{array}{l}0.013 * * \\
(0.007)\end{array}$ & $\begin{array}{l}0.01 \\
(0.02)\end{array}$ & $\begin{array}{l}0.01 \\
(0.02)\end{array}$ & $\begin{array}{l}0.01 \\
(0.02)\end{array}$ & $\begin{array}{l}0.02 \\
(0.03)\end{array}$ & $\begin{array}{l}0.02 \\
(0.02)\end{array}$ & $\begin{array}{l}0.02 \\
(0.03)\end{array}$ & $\begin{array}{l}0.03 * * * \\
(0.01)\end{array}$ & $\begin{array}{l}0.02 * * \\
(0.01)\end{array}$ & $\begin{array}{l}0.03^{* * *} \\
(0.01)\end{array}$ \\
\hline $\begin{array}{l}\text { Consumer } \\
\text { credit }\end{array}$ & $\begin{array}{l}0.04 * * * \\
(0.01)\end{array}$ & $\begin{array}{l}0.04 * * * \\
(0.01)\end{array}$ & $\begin{array}{l}0.04 * * * \\
(0.01)\end{array}$ & $\begin{array}{l}0.04 * * \\
(0.02)\end{array}$ & $\begin{array}{l}0.04 * * * \\
(0.01)\end{array}$ & $\begin{array}{l}0.04 * * * \\
(0.01)\end{array}$ & $\begin{array}{l}-0.01 \\
(0.06)\end{array}$ & $\begin{array}{l}-0.01 \\
(0.06)\end{array}$ & $\begin{array}{l}-0.002 \\
(0.06)\end{array}$ & $\begin{array}{l}-0.01 \\
(0.09)\end{array}$ & $\begin{array}{l}-0.01 \\
(0.09)\end{array}$ & $\begin{array}{l}0.01 \\
(0.09)\end{array}$ & $\begin{array}{l}0.05 \\
(0.04)\end{array}$ & $\begin{array}{l}0.003 \\
(0.02)\end{array}$ & $\begin{array}{l}0.04 \\
(0.04)\end{array}$ \\
\hline $\begin{array}{l}\text { Housing } \\
\text { credit }\end{array}$ & $\begin{array}{l}0.001 \\
(0.001)\end{array}$ & $\begin{array}{l}0.001 \\
(0.01)\end{array}$ & $\begin{array}{l}0.002 \\
(0.01)\end{array}$ & $\begin{array}{l}0.002 \\
(0.01)\end{array}$ & $\begin{array}{l}0.001 \\
(0.01)\end{array}$ & $\begin{array}{l}0.002 \\
(0.01)\end{array}$ & $\begin{array}{l}-0.01 \\
(0.02)\end{array}$ & $\begin{array}{l}-0.01 \\
(0.02)\end{array}$ & $\begin{array}{l}-0.01 \\
(0.02)\end{array}$ & $\begin{array}{l}-0.004 \\
(0.03)\end{array}$ & $\begin{array}{l}-0.01 \\
(0.03)\end{array}$ & $\begin{array}{l}-0.01 \\
(0.03)\end{array}$ & $\begin{array}{l}-0.01 \\
(0.05)\end{array}$ & $\begin{array}{l}-0.07 * * * \\
(0.03)\end{array}$ & $\begin{array}{l}-0.02 \\
(0.06)\end{array}$ \\
\hline$\Delta$ (Interest rate $)$ & $\begin{array}{l}0.001 \\
(0.01)\end{array}$ & & $\begin{array}{l}-0.01 \\
(0.01)\end{array}$ & $\begin{array}{l}0.0004 \\
(0.009)\end{array}$ & & $\begin{array}{l}-0.01 \\
(0.01)\end{array}$ & $\begin{array}{l}0.005 \\
(0.04)\end{array}$ & & $\begin{array}{l}0.02 \\
(0.03)\end{array}$ & $\begin{array}{l}0.01 \\
(0.04)\end{array}$ & & $\begin{array}{l}0.02 \\
(0.03)\end{array}$ & $\begin{array}{l}-0.06 \\
(0.04)\end{array}$ & & $\begin{array}{l}-0.04 \\
(0.04)\end{array}$ \\
\hline$\Delta(\text { Interest rate })_{t-1}$ & & $\begin{array}{l}-0.02 * \\
(0.01)\end{array}$ & $\begin{array}{l}-0.02 * \\
(0.01)\end{array}$ & & $\begin{array}{l}-0.02 * \\
(0.01)\end{array}$ & $\begin{array}{l}-0.02 * \\
(0.01)\end{array}$ & & $\begin{array}{l}-0.005 \\
(0.02)\end{array}$ & $\begin{array}{l}0.002 \\
(0.02)\end{array}$ & & $\begin{array}{l}-0.005 \\
(0.02)\end{array}$ & $\begin{array}{l}0.001 \\
(0.02)\end{array}$ & & $\begin{array}{l}0.01 \\
(0.01)\end{array}$ & $\begin{array}{l}0.01 \\
(0.01)\end{array}$ \\
\hline$\Delta \log ($ REER $)$ & $\begin{array}{l}0.01 \\
(0.01)\end{array}$ & $\begin{array}{l}0.01 \\
(0.01)\end{array}$ & $\begin{array}{l}0.01 \\
(0.01)\end{array}$ & $\begin{array}{l}0.01 \\
(0.01)\end{array}$ & $\begin{array}{l}0.004 \\
(0.01)\end{array}$ & $\begin{array}{l}0.005 \\
(0.01)\end{array}$ & $\begin{array}{l}-0.01 \\
(0.06)\end{array}$ & $\begin{array}{l}-0.01 \\
(0.06)\end{array}$ & $\begin{array}{l}-0.01 \\
(0.06)\end{array}$ & $\begin{array}{l}-0.0002 \\
(0.06)\end{array}$ & $\begin{array}{l}-0.001 \\
(0.06)\end{array}$ & $\begin{array}{l}0.003 \\
(0.05)\end{array}$ & $\begin{array}{l}0.06 \\
(0.04)\end{array}$ & $\begin{array}{l}0.04 \\
(0.04)\end{array}$ & $\begin{array}{l}0.07^{*} \\
(0.04)\end{array}$ \\
\hline $\begin{array}{l}\Delta \log (\text { Government } \\
\text { consumption })\end{array}$ & $\begin{array}{l}0.03 * * * \\
(0.01)\end{array}$ & $\begin{array}{l}0.03 * * * \\
(0.01)\end{array}$ & $\begin{array}{l}0.03 * * * \\
(0.01)\end{array}$ & $\begin{array}{l}0.03 * * * \\
(0.01)\end{array}$ & $\begin{array}{l}0.03 * * * \\
(0.01)\end{array}$ & $\begin{array}{l}0.03 * * * \\
(0.01)\end{array}$ & $\begin{array}{l}0.05^{* * *} \\
(0.02)\end{array}$ & $\begin{array}{l}0.05^{* * *} \\
(0.01)\end{array}$ & $\begin{array}{l}0.05^{* * *} \\
(0.01)\end{array}$ & $\begin{array}{l}0.05^{* *} \\
(0.02)\end{array}$ & $\begin{array}{l}0.05^{* * *} \\
(0.02)\end{array}$ & $\begin{array}{l}0.05^{* * *} \\
(0.02)\end{array}$ & $\begin{array}{l}0.04 * * * \\
(0.003)\end{array}$ & $\begin{array}{l}0.038^{* * * *} \\
(0.003)\end{array}$ & $\begin{array}{l}0.037 * * * \\
(0.003)\end{array}$ \\
\hline $\begin{array}{l}\text { Issuances of bonds, } \\
\text { equities, and loans }\end{array}$ & $\begin{array}{l}-0.002 \\
(0.003)\end{array}$ & $\begin{array}{l}-0.003 \\
(0.003)\end{array}$ & $\begin{array}{l}-0.003 \\
(0.003)\end{array}$ & $\begin{array}{l}0.005 * * * \\
(0.002)\end{array}$ & $\begin{array}{l}0.004 * \\
(0.002)\end{array}$ & $\begin{array}{l}0.004^{*} \\
(0.002)\end{array}$ & $\begin{array}{l}0.003 \\
(0.006)\end{array}$ & $\begin{array}{l}0.003 \\
(0.006)\end{array}$ & $\begin{array}{l}0.003 \\
(0.006)\end{array}$ & $\begin{array}{l}0.03 * * * \\
(0.01)\end{array}$ & $\begin{array}{l}0.03^{* * *} \\
(0.01)\end{array}$ & $\begin{array}{l}0.03 * * * \\
(0.01)\end{array}$ & $\begin{array}{l}0.18^{* *} \\
(0.07)\end{array}$ & $\begin{array}{l}0.36 * * \\
(0.17)\end{array}$ & $\begin{array}{l}0.17 * * \\
(0.07)\end{array}$ \\
\hline $\begin{array}{l}\Delta \log (\mathrm{OECD} \\
\text { GDP })\end{array}$ & $\begin{array}{l}0.18 * * * \\
(0.03)\end{array}$ & $\begin{array}{l}0.17 * * * \\
(0.03)\end{array}$ & $\begin{array}{l}0.17 * * * \\
(0.03)\end{array}$ & $\begin{array}{l}0.18 * * * \\
(0.03)\end{array}$ & $\begin{array}{l}0.17 * * * \\
(0.03)\end{array}$ & $\begin{array}{l}0.17 * * * \\
(0.03)\end{array}$ & $\begin{array}{l}0.17 * * * \\
(0.04)\end{array}$ & $\begin{array}{l}0.17 * * * \\
(0.04)\end{array}$ & $\begin{array}{l}0.17 * * * \\
(0.04)\end{array}$ & $\begin{array}{l}0.17 * * * \\
(0.03)\end{array}$ & $\begin{array}{l}0.17 * * * \\
(0.04)\end{array}$ & $\begin{array}{l}0.17 * * * \\
(0.03)\end{array}$ & $\begin{array}{l}0.13 * * * \\
(0.04)\end{array}$ & $\begin{array}{l}0.16 * * * \\
(0.03)\end{array}$ & $\begin{array}{l}0.14 * * * \\
(0.04)\end{array}$ \\
\hline$\Delta$ LIBOR & $\begin{array}{l}-0.08 \\
(0.15)\end{array}$ & $\begin{array}{l}-0.07 \\
(0.15)\end{array}$ & $\begin{array}{l}-0.05 \\
(0.15)\end{array}$ & $\begin{array}{l}-0.08 \\
(0.16)\end{array}$ & $\begin{array}{l}-0.06 \\
(0.16)\end{array}$ & $\begin{array}{l}-0.05 \\
(0.15)\end{array}$ & $\begin{array}{l}-0.22 \\
(0.21)\end{array}$ & $\begin{array}{l}-0.21 \\
(0.14)\end{array}$ & $\begin{array}{l}-0.24 \\
(0.17)\end{array}$ & $\begin{array}{l}-0.20 \\
(0.23)\end{array}$ & $\begin{array}{l}-0.18 \\
(0.16)\end{array}$ & $\begin{array}{l}-0.21 \\
(0.19)\end{array}$ & $\begin{array}{l}-0.08 \\
(0.14)\end{array}$ & $\begin{array}{l}-0.08 \\
(0.15)\end{array}$ & $\begin{array}{l}-0.13 \\
(0.15)\end{array}$ \\
\hline VIX & $\begin{array}{l}-0.01 \\
(0.01)\end{array}$ & $\begin{array}{l}-0.01 \\
(0.01)\end{array}$ & $\begin{array}{l}-0.01 \\
(0.01)\end{array}$ & $\begin{array}{l}-0.01 \\
(0.01)\end{array}$ & $\begin{array}{l}-0.01 \\
(0.01)\end{array}$ & $\begin{array}{l}-0.01 \\
(0.01)\end{array}$ & $\begin{array}{l}-0.01 \\
(0.01)\end{array}$ & $\begin{array}{l}-0.01 \\
(0.01)\end{array}$ & $\begin{array}{l}-0.01 \\
(0.01)\end{array}$ & $\begin{array}{l}-0.01 \\
(0.01)\end{array}$ & $\begin{array}{l}-0.01 \\
(0.01)\end{array}$ & $\begin{array}{l}-0.01 \\
(0.01)\end{array}$ & $\begin{array}{l}0.003 \\
(0.008)\end{array}$ & $\begin{array}{l}-0.01 \\
(0.01)\end{array}$ & $\begin{array}{l}-0.003 \\
(0.01)\end{array}$ \\
\hline $\begin{array}{l}\text { Lagged dependent } \\
\text { variable }\end{array}$ & $\begin{array}{l}-0.02 \\
(0.07)\end{array}$ & $\begin{array}{l}-0.02 \\
(0.07)\end{array}$ & $\begin{array}{l}-0.02 \\
(0.07)\end{array}$ & $\begin{array}{l}-0.04 \\
(0.06)\end{array}$ & $\begin{array}{l}-0.04 \\
(0.06)\end{array}$ & $\begin{array}{l}-0.04 \\
(0.05)\end{array}$ & $\begin{array}{l}0.28 \\
(0.24)\end{array}$ & $\begin{array}{l}0.27 \\
(0.21)\end{array}$ & $\begin{array}{l}0.26 \\
(0.21)\end{array}$ & $\begin{array}{l}0.23 \\
(0.25)\end{array}$ & $\begin{array}{l}0.23 \\
(0.22)\end{array}$ & $\begin{array}{l}0.20 \\
(0.22)\end{array}$ & $\begin{array}{l}0.02 \\
(0.05)\end{array}$ & $\begin{array}{l}0.02 \\
(0.05)\end{array}$ & $\begin{array}{l}0.01 \\
(0.04)\end{array}$ \\
\hline
\end{tabular}




\section{Appendix II. Cross-Country Dynamic Panel Regressions Results (concluded)}

\begin{tabular}{|c|c|c|c|c|c|c|c|c|c|c|c|c|c|c|c|}
\hline \multirow{2}{*}{$\begin{array}{l}\begin{array}{l}\text { Dependent } \\
\text { variable }\end{array} \\
\begin{array}{l}\text { Estimation } \\
\text { method }\end{array}\end{array}$} & \multicolumn{15}{|c|}{ Contribution of investment to real GDP growth } \\
\hline & $\begin{array}{l}\text { OLS } \\
\text { (Pooled) }\end{array}$ & $\begin{array}{l}\text { OLS } \\
\text { (Pooled) }\end{array}$ & $\begin{array}{l}\text { OLS } \\
\text { (Pooled) }\end{array}$ & $\begin{array}{l}\text { OLS } \\
(\mathrm{FE})\end{array}$ & $\begin{array}{l}\text { OLS } \\
\text { (FE) }\end{array}$ & $\begin{array}{l}\text { OLS } \\
\text { (FE) }\end{array}$ & $\begin{array}{l}\text { 2SLS } \\
\text { (Pooled) }\end{array}$ & $\begin{array}{l}\text { 2SLS } \\
\text { (Pooled) }\end{array}$ & $\begin{array}{l}\text { 2SLS } \\
\text { (Pooled) }\end{array}$ & $\begin{array}{l}\text { 2SLS } \\
\text { (FE) }\end{array}$ & $\begin{array}{l}2 \mathrm{SLS} \\
(\mathrm{FE})\end{array}$ & $\begin{array}{l}\text { 2SLS } \\
(\mathrm{FE})\end{array}$ & $\begin{array}{l}\text { GMM } \\
\text { (Arellano- } \\
\text { Bond) }\end{array}$ & $\begin{array}{l}\text { GMM } \\
\text { (Arellano- } \\
\text { Bond) }\end{array}$ & $\begin{array}{l}\text { GMM } \\
\text { (Arellano- } \\
\text { Bond) }\end{array}$ \\
\hline & (1) & (2) & (3) & (1) & (2) & (3) & (1) & (2) & (3) & (1) & (2) & (3) & (1) & (2) & (3) \\
\hline $\begin{array}{l}\text { Cross-section fixed } \\
\text { effect }\end{array}$ & No & No & No & Yes & Yes & Yes & No & No & Yes & Yes & Yes & Yes & Yes & Yes & Yes \\
\hline Instruments $^{1}$ & No & No & No & No & No & No & Yes & Yes & Yes & Yes & Yes & Yes & Yes & Yes & Yes \\
\hline $\operatorname{Prob}(J$-statistic $)$ & & & & & & & 0.32 & 0.32 & 0.30 & 0.25 & 0.24 & 0.21 & 0.83 & 0.66 & 0.81 \\
\hline Obs. & 1109 & 1094 & 1094 & 1109 & 1094 & 1094 & 1047 & 1047 & 1032 & 1047 & 1047 & 1032 & 1016 & 1016 & 1001 \\
\hline $\operatorname{Adj} . R^{2}$ & 0.29 & 0.29 & 0.29 & 0.29 & 0.29 & 0.29 & 0.13 & 0.13 & 0.14 & 0.15 & 0.16 & 0.18 & & & \\
\hline
\end{tabular}

Note: Robust standard errors are presented in parentheses. Asterisks $*, * * * *$ indicate statistical significance at the $10 \%, 5 \%$ and $1 \%$ levels, respectively. Corporate/consumer/housing credit is the corresponding contribution to total credit growth. Government consumption is expressed in annualized quarter-on-quarter percent changes. Issuances of bonds, equities, and loans are in real terms, deflated by CPI. Interest rate and Libor are the first-order differences of short-term interest rate and the LIBOR respectively. REER is the first-order difference of the logarithms of real effective exchange rate. Lagged dependent variable is the first lag of the dependent variable.

${ }^{1}$ The instruments for the 2SLS and GMM estimations include the first and second lags of global variables as well as their contemporaneous values, the first and second lags of credit variables, and the second lags of the dependent variable and domestic control variables. 


\section{Appendix III. Figure. Brazil-Specific VARX: Cumulative Impulse Responses to One-Standard-Deviation Shocks}

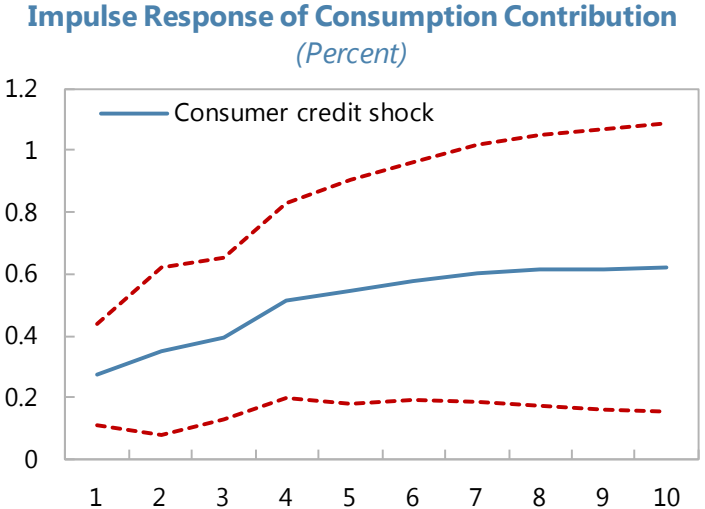

Impulse Response of Investment Contribution

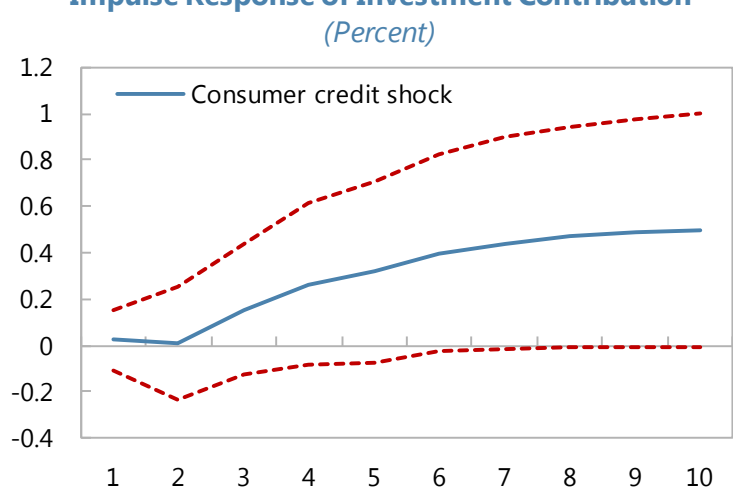

Impulse Response of Consumption Contribution (Percent)

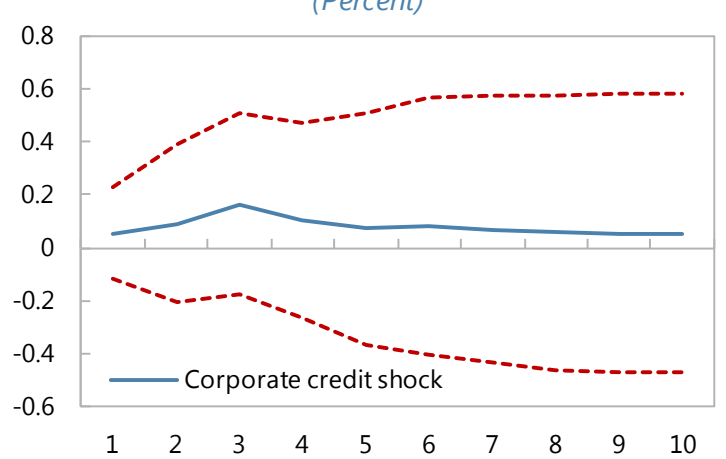

Impulse Response of Investment Contribution (Percent)

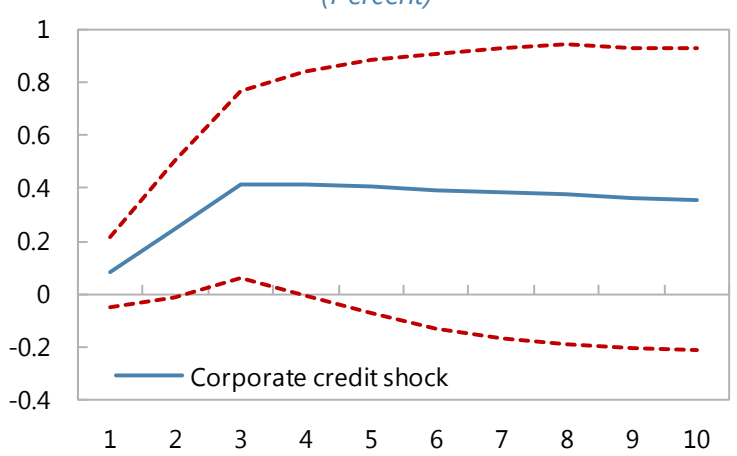

Impulse Response of Consumption Contribution (Percent)

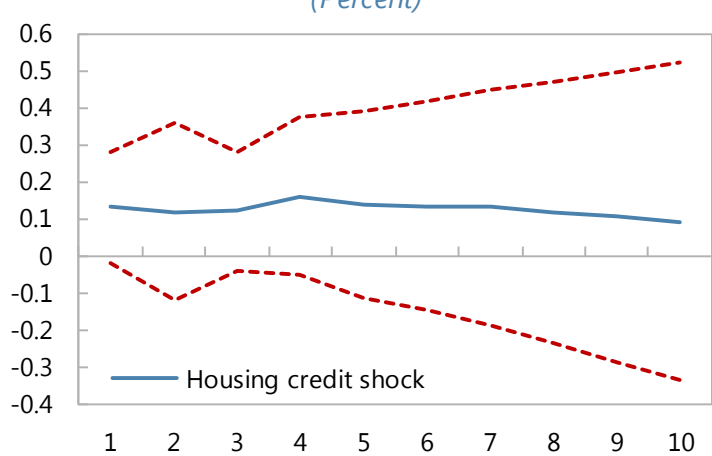

Impulse Response of Investment Contribution

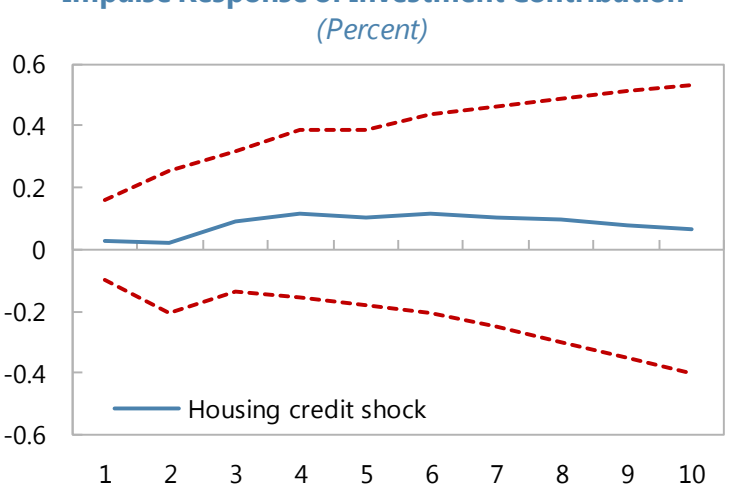

Sources: Haver Analytics; dXtime database; Dealogic database; Bloomberg database; IMF's International Financial Statistics (IFS) and Information Notice System (INS); and IMF staff calculations. 


\section{REFERENCES}

Agu, C.C., and J.O. Chukwu, 2008, "Toda and Yamamoto Causality Tests Between "BankBased" Financial Deepening and Economic Growth in Nigeria," European Journal of Social Sciences, Vol. 7, No. 2, pp. 175-84.

Ahmed, H., and S.M. Miller, 2000, "Crowding-Out and Crowding-In Effects of the Components of Government Expenditure," Contemporary Economic Policy, Vol. 18, No. 1, pp. 123-33.

Bassett, W.F., Chosak, M.B., Driscoll, J.C., and E. Zakrajšek, 2010, "Identifying the Macroeconomic Effects of Bank Lending Supply Shocks.”

Beck, T., B. Buyukkarabacak, F. Rioja, and N. Valev, 2012, "Who Gets the Credit? And Does It Matter? Househould vs. Firm Lending Across Countries," The B.E. Journal of Macroeconomics, Vol. 12: Iss. 1 (Contributions), Article 2.

Biggs, M., Mayer, T., and A. Pick, 2010, "Credit and Economic Recovery: Demystifying Phoenix Miracles".

Brigden, A., and P. Mizen, 1999, "Money, Credit and Investment in the UK Corporate Sector," ISSN 1368-5562, Bank of England.

Buyukkarabacak, B., and N. Valev, 2006, "Credit Expansions and Financial Crises: The Roles of Household and Firm Credit," Andrew Young School of Policy Studies, Research Paper Series 06-55.

Campbell, J.Y., and J.F. Cocco, 2007, "How Do House Prices Affect Consumption? Evidence from Micro Data," Journal of Monetary Economics, Vol. 54, No. 3, pp. 591-621.

Cottarelli, C., Dell'Ariccia, G., and I. Vladkova-Hollar, 2005, "Early Bird, Late Risers, and Sleeping Beauties: Bank Credit Growth to the Private Sector in Central and Eastern Europe and in the Balkans," Journal of Banking \& Finance, Vol. 29, pp. 83-104.

Dell'Ariccia, G., D. Igan, L. Laeven, and H. Tong, 2012, "Policies for Macrofinancial Stability: How to Deal with Credit Booms,” IMF Staff Discussion Note No. 12/06.

Driscoll, J.C., 2004, "Does Bank Lending Affect Output? Evidence from the U.S. States," Journal of Monetary Economics, Vol. 51, pp. 451-71.

Elekdag, S., and F. Han, 2015, "What Drives Credit Growth in Emerging Asia?", Journal of Asian Economics, Vol. 38, pp. 1-15. 
Fackler, J.S., and W.D. McMillin, 1998, "Historical Decomposition of Aggregate Demand and Supply Shocks in a Small Macro Model,” Southern Economic Journal, Vol. 64, No. 3, pp. 648-64.

Harrison, P., O. Sussman, and J. Zeira, 1999, "Finance and Growth: Theory and New Evidence," (Washington: Federal Reserve Board (Division of Research and Statistics)), mimeo.

Kai, G. and V. Stepanyan, 2011, "Determinants of Bank Credit in Emerging Market Economies," IMF Working Paper 11/51.

Levine, R., 2004, "Finance and Growth: Theory and Evidence," NBER Working Paper No. 10766 (Cambridge, Massachusetts: National Bureau of Economic Research).

Ludvigson, S., 1999, "Consumption and Credit: A Model of Time-Varying Liquidity Constraints," The Review of Economics and Statistics, Vol. 81, No. 3, pp. 434-47.

Mian, A., and A. Sufi, 2014, "Cash on Hand and Consumption: Evidence from Mortgage Refinancing," Booth School of Business, University of Chicago.

Nieh, C., and T. Ho, 2006, "Does the Expansionary Government Spending Crowd Out the Private Consumption? Cointegration Analysis in Panel Data," The Quarterly Review of Economics and Finance, Vol. 46, pp. 133-148.

Ocampo, S., and N. Rodriguez, 2012, "An Introductory Review of a Structural VAR-X Estimation and Applications," Revista Colombiana de Estadística, Vol. 35, No. 3, pp. 479-508.

Peek, J., E.S. Rosengren, and G.M.B. Tootell, 2003, "Identifying the Macroeconomic Effect of Loan Supply Shocks," Journal of Money, Credit and Banking, Vol. 35, No. 6, pp. $931-46$.

Peek, J., and J.A. Wilcox, 2006, "Housing, Credit Constraints, and Macro Stability: The Secondary Mortgage Market and Reduced Cyclicality of Residential Investment," American Economic Review, Vol. 96, No. 2, pp. 135-140.

Rondorf, U., 2012, “Are Bank Loans Important for Output Growth? A Panel Analysis of the Euro Area," Journal of International Financial Markets, Institutions \& Money, Vol. 22, pp. 103-19. 